University of Rhode Island

DigitalCommons@URI

Open Access Master's Theses

1981

\title{
INCREASING THE AGE OF MANDATORY RETIREMENT AND THE IMPACTS ON JOB MOBILITY IN RHODE ISLAND
}

Thomas H. Mitchell

University of Rhode Island

Follow this and additional works at: https://digitalcommons.uri.edu/theses

\section{Recommended Citation}

Mitchell, Thomas H., "INCREASING THE AGE OF MANDATORY RETIREMENT AND THE IMPACTS ON JOB MOBILITY IN RHODE ISLAND" (1981). Open Access Master's Theses. Paper 491.

https://digitalcommons.uri.edu/theses/491

This Thesis is brought to you for free and open access by DigitalCommons@URI. It has been accepted for inclusion in Open Access Master's Theses by an authorized administrator of DigitalCommons@URI. For more information, please contact digitalcommons-group@uri.edu. 
INCREASING THE AGE OF MANDATORY RETIREMENT

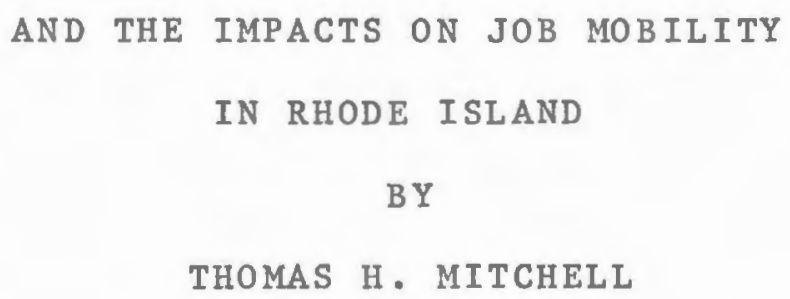




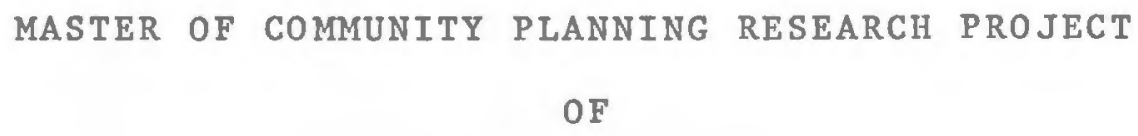

THOMAS H. MITCHELL

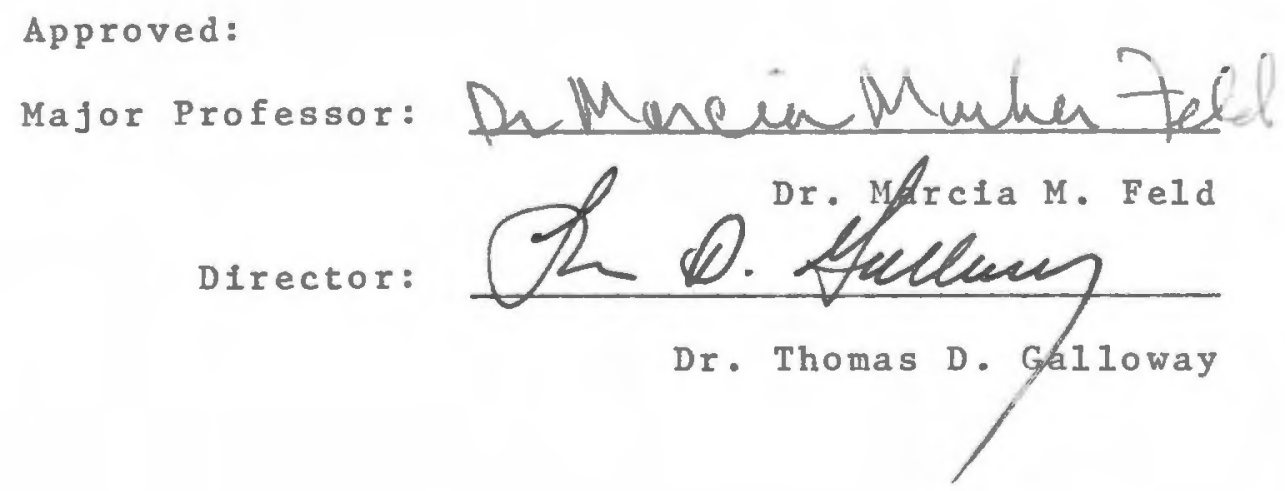




\section{ABSTRACT}

State economic development planning involves a complex series of interrelationships among many different areas. While land uses, transportation networks and economic conditions recelve the majority of attention in most economic development planning, human resources are an important and often underestimated resource.

In 1978, the Age Discrimination in Employment Act of 1967 was amended to allow workers to retire at age 70. Since worker retirements have historically created many job opportunities for younger workers, including both internal promotions and employment opportunities for workers entering the labor force for the first time, serious questions have been ralsed as to the impact of this legislation on the job mobility opportunities for younger workers, women and minorities. It has been speculated that a decrease in the job mobility opportunities for these groups will accelerate out-migration from Rhode Island, a development that will negatively affect the economic health and vitality of the state.

This research project will examine the impact of raising the age of mandatory retirement on the above mentioned groups of workers within the Rhode Island manufacturing community. In order to accurately assess the impacts, a mail survey of 107 manufacturing firms located in Rhode Island was conducted, which provided a 79 percent return of all questionnatres.

The results of this survey indicate that job mobility for younger workers will be impaired by allowing older workers to work for longer periods of time. In addition, employers predict that under continuing high rates of inflation, the trend toward early retirement before age 65 will be completely reversed. 


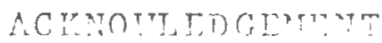

Lifo any creative effort, a thesis project is nover solely the nroluct of one person. "rumerous incividuals have provided technical assistance in the development of this effort, including Mr. Daniel Varin, Mr. Patrick Fincliss and 'ir. Jonn C'brien of the nhode Island office of State Planing; ar. Tuvarc Lecuc of the rolitieat science deratrent of the Lniveraity of Rlode Islan:, ar: r.r. Sarcia "'. Fela of tho rraduate Curriculur. in contunity Tlanuing and irea jevelopnent of tre iniversity of rin te Island. Collectively, tiejr comments helieú inprove tire lirection an content of tlis project.

Finaliy, no creative effort can be consleted itiout time, understancing, and love. "y vife Penui provided all. these, and to her I will be forever indelted. 


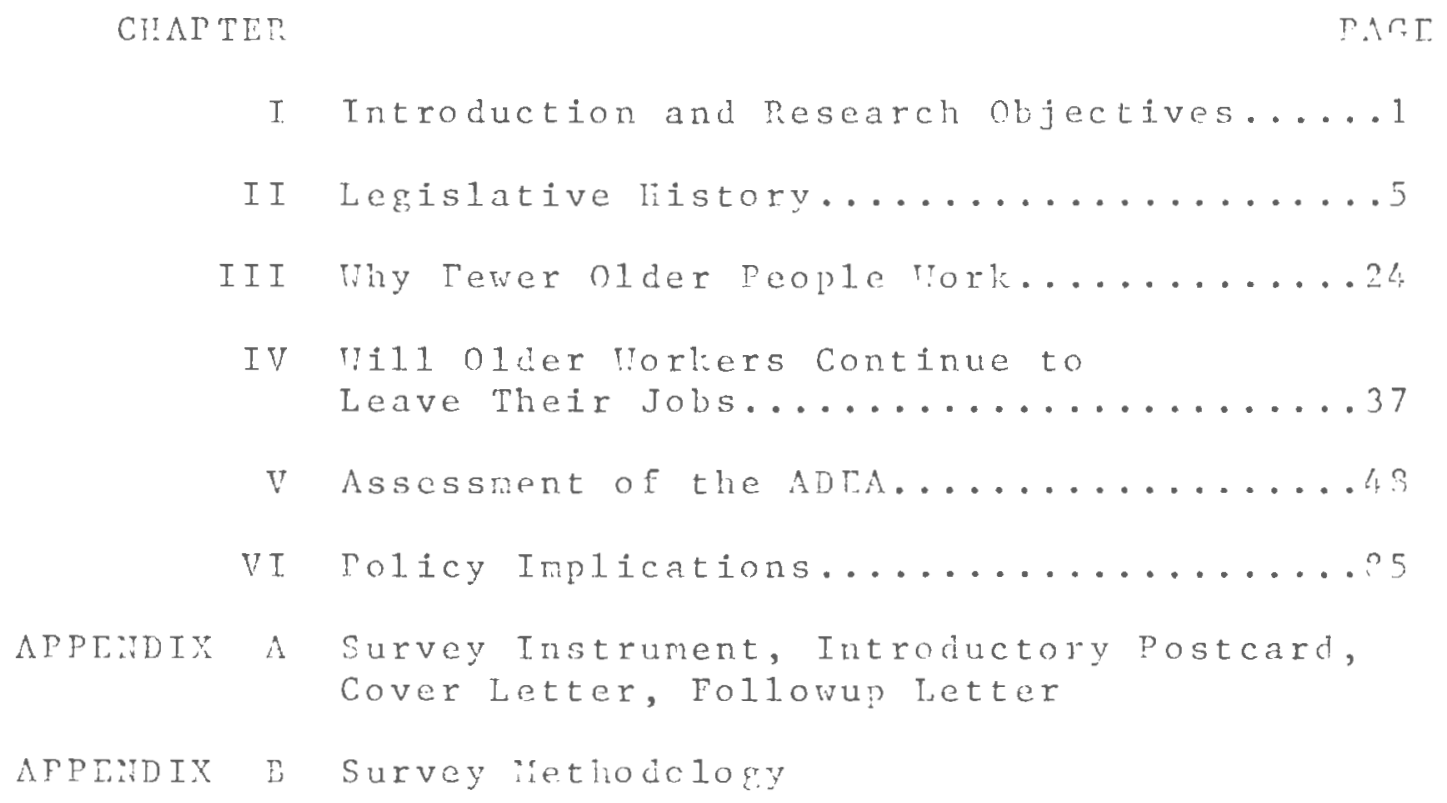


Table

Number

Title

Page

I I -1

Age Discrimination Cases Filed In Rhode

Is land

III-1 Civilian Labor Force Participation Rates;

Annual Averages

III-2 Labor Force Participation Rates by Age Groups

III-3 Social Security Coverage

II I -4

Percentage of Insured Workers Aged 62 to 64 Receiving OASI Benefits, Selected Years $1957-1976$

III -5

Percentage of Men Receiving Social Security Disability Benefits, Selected Years 1957-72

III-6 Real Replacement Rates After 5, 10, 15 and 20 Years of Retirement with Alternative Rates of Inflation

Completed Surveys by SIC Code

Years $1 \mathrm{n}$ Business for Surveyed Firms

Mandatory Retirement Policies

Crosstabulation: Mandatory Retirement Policies by Firm Size

Retirement Age for White Collar Workers 


\begin{tabular}{|c|c|}
\hline$v-11$ & $\begin{array}{l}\text { Do You Expect Employees to Nork Past } \\
\text { Age } 65\end{array}$ \\
\hline$\nabla-12$ & W111 Certain Groups Work Longer \\
\hline$v-13$ & $\begin{array}{l}\text { Groups Expected to Remain in the Workforce } \\
\text { Past Age } 65\end{array}$ \\
\hline$V-14$ & $\begin{array}{l}\text { Firms Which Allowed Workers to Work Past } \\
\text { Age } 65\end{array}$ \\
\hline$V-15$ & $\begin{array}{l}\text { Percent of Workers Age } 65 \text { Who Have Kept } \\
\text { Working }\end{array}$ \\
\hline$V-16$ & Will Certain Groups Work Longer \\
\hline$V-17$ & $\begin{array}{l}\text { Groups Expected to Remain in the Workforce } \\
\text { Past Age } 65\end{array}$ \\
\hline$v-18$ & Will Mandatory Retirement Be Abolished \\
\hline$V-19$ & Affect of Abolishing Mandatory Retirement \\
\hline$v-20$ & $\begin{array}{l}\text { Crosstabulation: Retirement Policy by Affect } \\
\text { if Abolished }\end{array}$ \\
\hline$v-21$ & $\begin{array}{l}\text { White Collar Workers that Retire Before Age } \\
65\end{array}$ \\
\hline$v-22$ & $\begin{array}{l}\text { Blue Collar Workers that Retire Before Age } \\
65\end{array}$ \\
\hline$v-23$ & $\begin{array}{l}\text { Crosstabulation: Early Retirement by White } \\
\text { Collar Workers and Blue Collar Workers }\end{array}$ \\
\hline$V-24$ & Personnel Pollcies for Older Workers \\
\hline$v-25$ & $\begin{array}{l}\text { Expect Changes in National Trend Toward } \\
\text { Early Retirement }\end{array}$ \\
\hline$v-26$ & $\begin{array}{l}\text { Increasing the Eligible Age for Social } \\
\text { Security Benefits }\end{array}$ \\
\hline$v-27$ & $\begin{array}{l}\text { Expect Different Work Patterns for Men and } \\
\text { Women }\end{array}$ \\
\hline$v-28$ & Employee Appraisal systems \\
\hline$v-29$ & Effect on Employee Appraisal Systems \\
\hline$v-30$ & How Do You Provide Retraining \\
\hline
\end{tabular}




\begin{tabular}{|c|c|}
\hline-31 & Tetrain licier torkers \\
\hline$v-32$ & rill Retraining Mlool Alvancement \\
\hline$v-33$ & $\begin{array}{l}\text { Crusstabulation: Mill retraining Bloci } \\
\text { Alvancement by SIC Code }\end{array}$ \\
\hline$V-34$ & Policies Toward liring older rorlers \\
\hline$v-33$ & Inflation and the retirement becision \\
\hline$r-36$ & $\begin{array}{l}\text { Iripact on JoL Opportunitics for Different } \\
\text { Groups }\end{array}$ \\
\hline
\end{tabular}




\section{CIAPTER I}

\section{INTRODUCTION}

Historically, work in America has been characterized by competition among the various sroups comprising the lator force. The nature and extent of this competition has characterized the context of many public policy decisions. For example, legislation by the Federal rovernment to restrict imports or the implementation of imigration lars that linjt the number of foreign born allowerl to emigrate to this country are instances of overt uses of public policy to mollify external forces affecting the degree of competition for work within the economy.

In addition to the use of public policy as an instrument to exert direct control over external forces that affect the nature and degree of competition in the workplace public policy has also been used as a vehicle to influence indirectly the forces that affect those currently competing for work. Thus, policies designed to increase employment for the handicapped, women, minorities or the unemployed as well as policies designed to regulate the minimum vages, maximum hours and other standards of wort: can be viewed as public policy attempts to mediate between the competing interests within the vorkforce. 
It is within this framework of competition for work that the issues of job opportunity and occupational mobility can be viewed. Numerous examples exist of public policies designed to increase the opportunity of workers to compete in the labor force. Perhaps the best example of a comprehensive public policy designed to assure all Americans the right to equal opportunity in the workforce has been the Civil Rights Act of 1964, which under Title VII outlawed discrimination in employment based on sex, race, color, religion and national origin.

While the question of increasing the opportunity to compete for work in the labor market has been addressed through legislation such as the Civil Rights Act of 1964 , occupational mobility has never been the subject of any comprehensive legislation. Although occupational or job mobility has a variety of facets, it is most commonly associated with the ability of workers to advance along the occupational ladder through increases in skill, responsibility, independence and income. Attempts to address the issue of occupational or job mobility through public policy would be particularly problematic, as internal mobility tends to be a function of torker skill and employer demand.

However, recent federal legislation has taken a dramatic step toward increasing the right of older workers to postpone retirement until age 70 . This policy raises serious questions as to the impacts of this legislation on 
the job mobility for younger workers, women, and minorities. In 1973, the Age Discrimination in Employment Act (ADEA) of 1967 was amended to allow workers to remain in the labor force until age 70 , an action the congressional Quarterly Almanac regarded as "probably the most far reaching social measure enacted by the 95 th Congress."l

The implications of this public policy change for the state of Rhode Island, where labor force participation is approximately 2 percent higher than the rest of the country and increasing, and where we have an aging labor force, suggest that job mobility for younger workers, women and minorities may be impaired, driving many of these workers from the state. Such a development would be contrary to state economic development goals, which seek a population distribution that will contain fewer proportional members of the dependent population groups, namely young children and retired aduits, who must be supported by those in the labor force. Thus, societal trends, like those foreshadowed by increasing the age of mandatory retirement, have serious implications for the economic health and vitality of the state.

This research project will examine the impact of the 1978 amendment to the ADEA of 1967, focusing specifically on the question of the potential impact on job mobility for younger workers, women and minorities. This project will concentrate on these impacts for manufacturing firms 1ocated in Rhode Island and will use the employer as the unit of analysis. The principal research objectives are: 
1. To determine the short-term impact of the legislation for younger workers, women and minorities.

2. To determine the probable impact on worker retirement decisions under continued rates of high inflation.

To achieve these objectives, It was necessary to conduct extensive original research, including a survey of 107 manufacturing firms currently located in Rhode Island.

The second chapter traces the relevant legislation concerning the increase in the age of mandatory retirement. The third chapter examines the historical trends toward early retirement and the fourth chapter discusses the research findings of other authors. The fifth chapter examines the resalts of the survey and the final chapter discusses the Implications for Rhode Island. 
CHAPTER II

\section{LEGISLATIVE HISTORY}

Perhaps the most salient characteristic of social legislation passed during the $1960^{\prime}$ 's has been the expansion of opportunity for all Americans. One of the least controversial, and possibly one of the most profound in terms of its impact on all workers, was the passage of the Age Discrimination in Employment Act of 1967 which proscribed discrimination in employment on the basis of age against persons between the ages of 40 and 65 . The Age Discrimination in Employment Act (ADEA) added another group of protected employees to those delineated in other civil rights legislation, most notably Title vil of the Civil Rights Act of 1964, which prohibited discrimination in enployment based on sex, race, color, religion and national origin

$$
\text { Ilistorically, different categories of discrimination }
$$

have displayed distincitve characteristics both as to the nature of the discrimination itself and the history of legal responses to it. Although the ADEA is historically linked to Title VIT of the Civil rights Act of 1964 , it has followed its own separate and distinct path. Section 715 of the 1964 Civil Rights Act directed the Secretary 
of Labor to study the problen of age discrimination and report his findings to Congress.

The Department of Labor completed this report in 1965 and found that approximately half of all private sector job openings were 1 imited to applicants below age 55; sinilarly, persons atove age 45 rould not be considered for about one-fourth of a11 job openings. The Secretary of Labor, Tillard lirtz, concluded that are discrimination vas widespread, and prosented serious consequences for older workers as individuals and the vation's economy. After careful study, the secretary concluded that nonstatutory methods of dealing with age discrimination would not prove fruitful, and that Congressional action was waranted.

In January, 1967, President Johnson issued a call for action to prohibit age discrimination in employment during his Message on Older Americans. Less than one month later, a bill was introduced to combat age discrimination and on June 12, 1968, the Age Discrimination in Employment Act of 1967 (P.L. 90-202, 29 U.S.C. 621) became 1aw.

Although President Johnson displayed concern for the welfare of older Americans in many areas, his specific concern over the employment prospects for older Americans was prompted by the unemployment rate for older workers. Historical1y, unemployment rates are highest for workers younger than 25 years of age for many reasons. For example, younger workers $1 \mathrm{ack}$ both seniority and the skills of 
i. any older worlers. Tinemployrent rates for workers taroughout tic inited states steacily cecreases until vorliero reacis tise arge of forty-five, at rilich point emplowrent rates agitn begin to increase. This trenc las leen cvident sirce 1940 and is generally accurate for al1 woriers. reriaps nore important than the rate of unemployment is the trend relative to the duration of unenploynent for older worlers. In 1067, nearly 25 percent of all unemployed malc rorlers older than 45 years of ase were unenployci longer than fifteen (15) weels..$^{2}$ Iy contrast, the 1975 duration of unemployment for all workers was nearly 16 weelis, but the duration of unerploynent for vorhers 55 years and older was nore than 23 veelis. 3 It is important to note that statistics relating to unomployment for older vorkers must be considered conservative estimates as many older worliers faced with the prospect of long-term unemployment will simply retire or dron out of the labor force. In addition, recent nationride stucjes conducted in 1977 and 1970 at the Vational opinion nesearch Center clearly show that while fer vorlers older than 5 ? years of age expected to lose their job within the next year, over 50 percent thought they rould experience difficulty in securing, anotier job with commensurate pay and beneits. ${ }^{4}$

The distribution and severity of the unemploynent burden and the programs appropriate to deal tith it are 
of obvious concern to policy makers and it is within this context that the Congress considered the Age Discrimination in Employment Act of 1967. Generally, the act was designed to reduce two distinct elements in the unfairness of prevailing hiring and firing practices. First, it attempted to end the discrimination that resulted from a misunderstanding of the relationship between age and job performance. Second, it attempted to end the discrimination that resulted from a deliberate desire or willingness to take advantage of a chronological fact. Although originally passed in 1967 , the act has been amended in 1974 and 1978 .

Among the original statement of findings and purpose, Congress declared that older workers faced difficulty in retaining jous, securing employment once unemployed, were subjected to arbitrary age limits in employment that vorked to the disadvantage of older workers; and in industries affecting commerce, were subject to arbitrary discrimination in employment, burdening commerce and the free flov of goods in commerce. ( $\triangle D E A$, Section 2(a)). The purpose of the act was to:

\footnotetext{
"promote employment of older persons based on their ability rather than age; to prohibit arbitrary age discrimination in employment; to help employers and workers find ways of meeting problems arising from the impact of age on employment." (ADEA, Section 2(b)).
}

Generally, the 1967 act made it illegal to fire or to refuse to hire applicants solely because of age. Em- 
ployment agencies were forbidden to refuse to refer applicants to job openings because of age. The act all but prohibited placing want ads specifying age preferences and it forbade labor unions to exclude or expel people from membership because of age. However, under section 4(f) the act did not prohibit hiring on the basis of age when age was "a bona fide occupational qualification reasonably necessary to the normal operation of the particular business", or where the differentiation "is based on reasonable factors other than age." (1967 ADEA Section 4(f)(1)). As an example of a bona fide occupational qualification, a job advertisement calling for a child actor for a youthful role in a movie or play would be a legitimate advertisement. Also, a differentiation based on reasonable factors other than age might involve an occupation where physical strength or other physical ability is important to the health and safety of the worker, as in the case of air traffic controllers or law enforcement officials. Section 4(f) of the original act outlined the exceptions to the extent of coverage intended under the act, and as might be expected, proved to be a source of confusion between employees and employers, ultimately resulting in a number of court cases and necessitating amendments to the act. One of the three exceptions provided under section 4 (f) allowed employers to observe the terms of a "bona fide seniority system or any bona fide employee benefit plan", 
such as a retirement or insurance plan, which is not "a subterfuge to evade the purposes of this Act, except that no such employee benefit plan shall excuse the failure to hire any individual." (ADEA, Section 4(f)(2). Generally, this provision, initiated by New York Senator Jacob Javits, was intended to allow for differential fringe benefits for newly hired older workers. Javits' concern was prompted by his belief that in the absence of this provision, "employers might actually have been discouraged from hiring older workers because of the increased costs involved in providing certain types of benefits to them." 5 Finally, the least controversial exception, Section 4(f)(3), did not make it unlawful for employees to be discharged or otherwise disciplined for good cause.

The original Age Discrimination in Employment Act of 1967 also called for a study of the institutional and other arrangements which encourage involuntary retirement, to be conducted by either the Department of Labor or by contract. This study has not been completed, but is currently in progress.

originally, enforcement responsibility was given to the U.S. Department of Labor, Employment Standards Administration. Aggrieved individuals were able to bring a civil action in court against employers, as long as the employer had twenty-five or more employees for each working day in each of twenty or more calendar weeks in the current or preceding calendar year. The act also covered employment 
agencies and labor organizations. As origina1ly passed, the Act's coverage was extended to individuals at least forty (40) years of age but less than sixty-five (65) years of age.

Since its passage, the Act has been amended in 1974 and 1978. The 1974 amendments (P.L. 93-259) expanded the number of employees covered under the Act by including employees of a State or a political subdivision of a state. In addition, the 1974 amendments also covered nondiscrimination on account of age in Federal government employment and authorized the Civil Service Commission to enforce the provisions in the act relating to Federal Civil service employment. Significantly, the coverage of the Act was revised to include employers of twenty (20) or more employees, consistent with changes in the Fair Labor Standards Amendments of 1974 (P.L. 93-259, Section 28, enacted April 8, 1974). Enforcement procedures are essentially similar to those of the Fair Labor Standards Act, with the most significant difference relating to the requirement that the secretary of Labor attempt to "eliminate discriminatory practices through informal methods of conference, conciliation and persuasion before instituting any legal proceedings." A11 covered employers, employment agencies and labor organizations are required to post, in a conspicuous place on the premises, official notices outlining the rights of individuals covered by the Act. 
The 1978 Amendments to the Act (P.L. 95-256) contained a number of provisions extending the age group of employees who are protected by the provisions of the Act. Generally, the act prohibited the mandatory retirement of workers under age 70 solely on the basis of age. Two significant exemptions were, however, allowed. First, it permitted the compulsory retirement of "bona fide executives" or those in "high policymaking positions at age 65 where such executives have maintained their positions for at least two years prior to retirement" and are entitled to an "immediate, nonforfeitable retirement benefit from their current employer's plan or plans of at least $\$ 27,000$ annualy, exclusive of their own contributions and Social Security." (ADEA, Section 12(c)). Second, it allowed, until June 30,1982 , the involuntary retirement of teachers at age 65 where such individuals serve under contracts of unlimited tenure at institutions of higher education, as defined by Section 1201 of the Higher Education Act of 1965 . (ADEA, Section $12(d))$.

At this point it should be noted that the ADEA does not preempt state law (Section 14(a)). For example, manditorily retiring workers at age 70 , although permitted under the ADEA may violate a particular state's law prohibiting mandatory retirement at any age. In fact, a number of states Alaska, Connecticut, Hawai, Illinois, Iowa, Maine, Maryland, Michigan, Montana, Nevade, New Jersey, North Carolina, and West Virginia - place no upper age limit on the retirement of older workers. In addition, Alaska and Montana do 
not permit the bona fide pension plan exemption.

In Maine, public sector employees may not be forced to retire solely because of age and Florida law contains similar coverage for state employees. Similar coverage was extended to city workers by the cities of Los Angeles, California and Seattle, Washington.

As a result of the section 14(a) provision, the impact of the 1978 amendments on companies which operate in the above mentioned states is academic as state 1 aw supersedes federal law when the state law allows a more liberal definition of retirement age. In addition, companies that operate in several states may be forced to abandon mandatory retirement as a matter of corporate policy.

In summary, the ADEA of 1967, as amended through 1978 , covers workers age 40 to 70 . The act covers all firms employing 20 or more persons and protects these workers from arbitrary age discrimination in hiring, discharge, pay, promotions, fringe benefits and other aspects of employment. In addition, the Act's provisions also extend coverage to labor organizations of 25 or more members, Federal, state, and local government, and employment agencies that serve covered employers. Enforcement responsibility for the ADEA was transferred to the Equal Employment Opportunity Commission from the U. S. Department of Labor on July 1,1979 as part of President Carter's Reorganization Plan No. 1. The law prohibits the involuntary retirement of workers before age 70 in all but two cases. First, employees of at 
least 65 years of age serving in a bona fide executive or high policy-making position and entitled to an annual benefit of $\$ 27,000$ or more on retirement may be involuntarily retired. In general, the definition of a bona fide executive or high policy-making employee is intended to cover the head of a significant and substantial local or regional operation of a corporation, such as a major production facility or retail establishment, but not the head of a minor branch, warehouse or store. 7 In addition, the head of a division such as finance, marketing, or production and manufacturing at a corporate headquarters would be included, as would top-level employees without supervisory responsibilities such as chief economists or chief research scientists of corporations. 8

The second exemption from the prohbition on mandatory retirement permits, until July 1, 1982, the compulsory retirement of teachers between the ages of 65 and 70 who have unlimited tenure at institutions of higher education, as defined by Section 1201 (a) of the Higher Education Act of 1965. Effective September 30,1978 , the upper age 1imit on the coverage of the Act for Federal employees was removed.

Exemptions to the age requirement or 1 imit fall essentially into three broad categories. First, where age is a bona fide job qualification, such as actors required for youthful roles. Second, where the age requirement is part of a bona fide seniority system or employee benefit 
plan, except that mandatory retirement based on age is prohibited until age 70. Generally, this exemption was intended to allow age to be considered in funding a retirement benefit plan and to determine the level of benefits to be paid. It also permits an employer to exclude a newly hired older worker from certain limited fringe benefit plans where it would be too costly to fund his or her anticipated benefit in the short time before he or she reaches the upper age limit of the Act. Nothing in the Act is designed to force employees to remain in the workforce longer than they want to remain. For example, pension plans which call for retirement based on a years of service formula, such as the "thirty years and out" retirement system found in many manufacturing industries are not directly affected by the Act. Significantly, the Act does not deal with the issue of voluntary retirement, but is concerned with the issue of involuntary or mandatory retirement. Forced retirements before age 70 are illegal, except for the previously noted exemptions. Voluntary separation from the labor force before age 70 , for health or other personal reasons, is not affected by the Act. Complaints are currently investigated by Equal Employment Opportunity Commission (EEOC) specialists who attempt to reconcile such cases administratively. Where such attempts prove unsuccessful, the EEOC may file court action. Under Federal law, any person age forty years and older, discriminated against on account of age by any em- 
ployer of 20 or more persons, labor organizations of 25 or more members, employment agencies serving covered employers or Federal, state and local governments may bring a civil action in any Federal district court, and must file a charge of unlawful discrimination with the EEoc and, in states with an age discrimination law, with the state agency responsible for the enforcement of that 1 aw. This charge must be filed not less than 60 days before taking court action and within 180 days of the alleged violation. If the state takes action under its own discrimination law, the 180 day restriction is increased to 300 days.

In 1979 , the U.S. Supreme Court resolved an Important procedural question of the ADEA which had created a conflict among the circuit courts of appeal. In Oscar Meyer v. Evans, the Court ruled that alleged victims of discrimination under the Act must first resort to State Administrative agencies, where available, before pursuing a claim to the Federal level. These Federal claims can only be filed after 60 days following the commencement of State proceedings. The Court also resolved the issue of what rights a claimant has if state jurisdictional requirements, such as a time limit, cannot be met. In such cases, the Court reasoned, an individual's Federal rights remain intact, but the individual must make the potentially futile act of filing a state claim.

The significance of this ruling lies in the fact that enforcement of the ADEA rests, at least initially, with the 
designated State agency. Until 1978, that responsibility was charged to the R. I. State Department of Labor. However, under President Carter's Reorganization Plan No. 1, administrative responsibility for the ADEA is now the domain of the State EEOC, located in Rhode Island under the Commission for Human Rights, as of September $30,1980$. Under Rhode Is land state law, age discrimination in employment is covered under Title 28 , Labor and Labor Relations, general1y referred to as the State Fair Employment Practices Act (FEPA) of 1956, as amended. In 1979, Chapter 28-5 of that Act was amended to include age in the protected categories of race or color, religion, sex, physical handicap or country of ancestral origin. Consistent with the Federal definition, the protected age groups were constructed to include anyone between the ages of forty (40) and seventy (70), inclusive. (Section 28-5-6, (I)). In addition, state law, as set forth under the Fair Employment Practices Act, includes all employers of four (4) or more individuals, (Section 28-5-6 (B)) thereby extending coverage of the age discrimination provisions to a greater number of workers than covered under Federal law. Although employers of firms that employ four (4) or more persons but fewer than twenty (20) persons, who believe they have been discriminated against on the basis of age, may bring their complaint to the State Commission for Human Rights, they would be precluded from filing a complaint to a Federal court. Rhode Island State law also provides a more 
liberal definition of a labor organization, as there is no provision specifically stating the size of the labor organization.

In 1976, the U. S. Department of Labor estimated that about 70 percent of all workers in the United States between the ages of 40 and 65 were covered under provisions of the ADEA. ${ }^{9}$ Despite Rhode Island's more liberal coverage, the age discrimination provisions under state law are conservatively estimated to cover over 40 percent or approximately 80,000 men and women employed in Rhode Island businesses and industries. Coverage under the provisions of Federal law is conservatively estimated to extend to approximately 12 percent of al1 employees or 12,000 workers. These estimates are considered conservative as they assume that all workers employed in businesses or industries with fewer than 4 employees are in the protected age range of 40 to 70 , an assumption that undoubtedly deflates the actual number of workers covered under the legislation. Specific breakdowns on the age of workers employed by firm size was not available, and in the absence of these data, the preceding estimates must be considered to represent the lower boundary for the number of workers covered under age discrimination legislation.

In attempting to assess the impact of the Act since its passage, the U. S. Department of Labor released figures on the age discrimination complaints from 1969 to 1976 . The number of complaints received each year by the secretary 
rose from approximately 1,000 in 1969 to over 5,121 by 1976. 10 This rise in complaints can be attributed to the increase in the number of workers covered, a greater awareness of the ADEA by workers, and insufficient economic growth in recent years to provide full employment and its 1 ingering effect on the older worker.

Generally, Rhode Island followed a similar trend with respect to workers filing age discrimination cases. The Rhode Island Department of Labor, which had jurisdiction for employment of the law until september, 1979, reported the following cases:

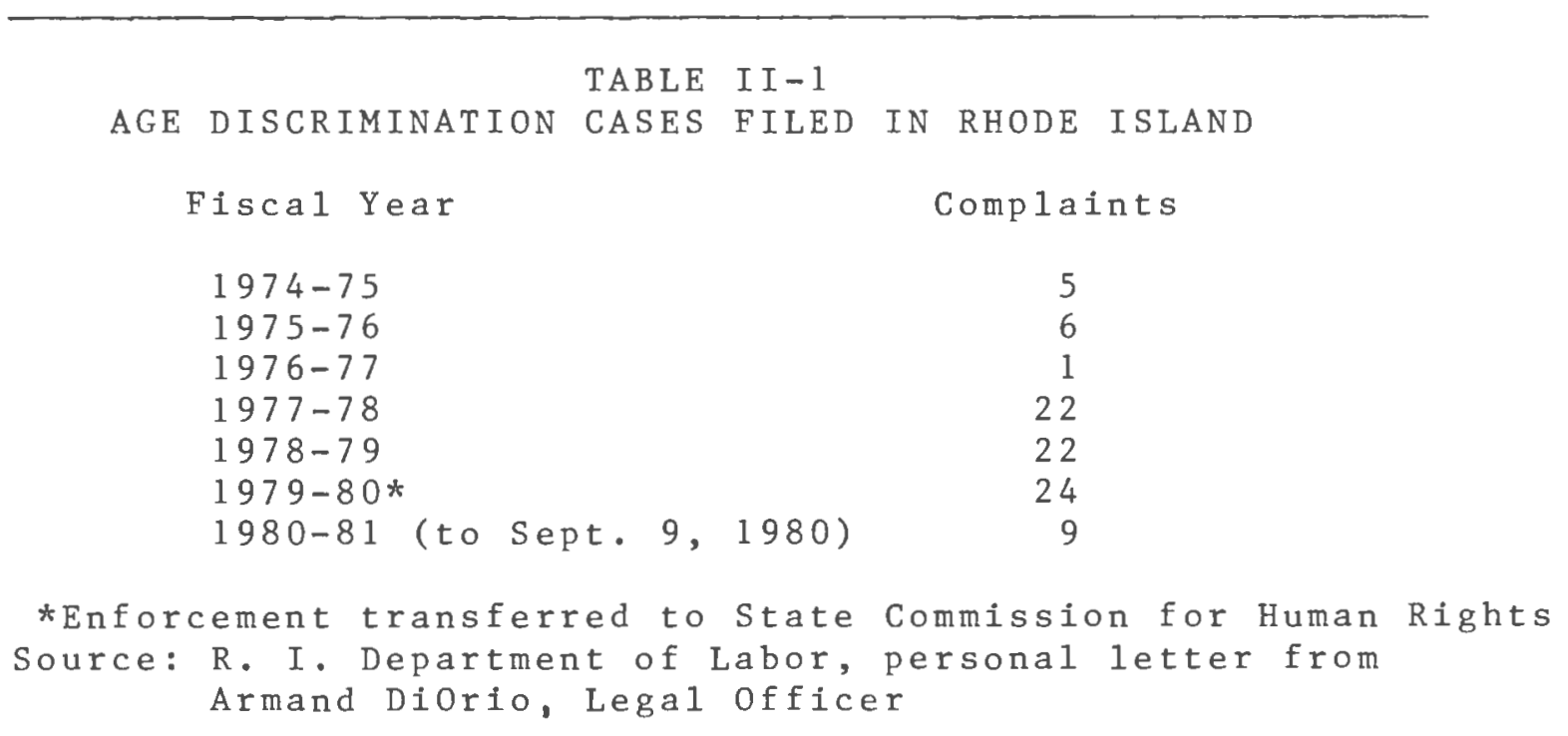

According to the Annual Report filed by the State Commission for Human Rights, the agency has experienced a significant number of charges filed on the basis of age. 11 In addition, manufacturing industries accounted for almost half of all age discrimination charges. 
During Congressional testimony concerning the impacts of raising the age of mandatory retirement to age 70 , a variety of witnesses representing both the public and private sector raised a number of arguments either in favor of or in opposition to increasing the age of mandatory retirement. While a lengthy analysis of the testimony is unwarranted, a discussion of the major arguments would be useful in understanding the concerns of many witnesses.

Advocates in favor of leaving the age of mandatory retirement at 65 offered the following major arguments:

(1) older workers are, as a group, less suited for some jobs because they typically have less education, declining physical and mental capacity, are more resistant to change and do not learn new skills as easily as do younger workers.

(2) medical science has yet to develop an effective technique or set of techniques to guage the physical and mental health of employees.

(3) mandatory retirement for all employees is evenhanded and treats all employees uniformly, sparing unproductive older workers from the embarrassment of being fired or laid off.

(4) management is better able to plan its workforce needs if it knows that workers will retire at a certain age.

(5) older workers represent a more expensive workforce as employers must pay higher premiums for health insurance, life insurance, pensions and other fringe benefits.

(6) mandatory retirement creates new job opportunities as we 11 as advancement opportunities for younger workers.

(7) older workers can receive social security or other retirement income, while younger workers do not have any other income. 
(8) compulsory retirement is easiest for management as it precludes the need for extensive employee appraisal systems and reduces the likelihood that workers will bring suit against the company for age discrimination.

(9) affirmative action goals will be more difficult to achieve as workers will delay retirement, thereby creating fewer employment opportunities.

Advocates in favor of increasing the age of mandatory retirement from age 65 to age 70 or beyond, offered the following arguments in their testimony to Congressional subcomittees:

(1) mandatory retirement based solely on age is discriminatory, contrary to equal employment opportunity and a violation of constitutional rights concerning equal protection of the 1 aw.

(2) chronological age alone is a poor indicator of the ability of a person to be productive on the job.

(3) enforced idleness brought about as a result of retirement can have adverse psychological and physical effects on older workers.

(4) mandatory retirement is based on misconceptions about the ability of older workers to perform on the Job.

(5) mandatory retirement can cause financial hardships for older persons, particularly those older workers who would like to continue working in order to pay certain financial obligations usually considered common for younger people, such as a home mortgage, installment payments on cars and their children's college tuition.

(6) forced retirement discriminates against many women who have exhibited a discontinuous work pattern, interrupted by home or child care responsibilities, and who have not had the opportunity to become vested for pension benefits.

(7) compulsory retirement increases the drain on the social security system and private pensions by forcing workers to participate in these systems prematurely. 
(8) mandatory retirement is based on the myth that older workers must make room for younger workers.

(9) forced retirement causes a reduced gross national product through the loss of skills and experience possessed by older workers.

(10) employer pension costs for older workers can be reduced by restructuring or negotiating changes in pension plans for older workers who work past the "normal retirement age."

Thus, the arguments both for and against mandatory retirement, to a large extent, seem to be reverse images of each other. As a case in point, pension and fringe benefit costs for older workers are undeniably higher than are these same costs for younger workers. Proponents of eliminating mandatory retirement would argue that this need not be the case, as the pension and fringe benefit package available to workers is a negotiable issue. Congressional testimony by representatives of the national AFL-CIO claimed that in fact the issue of retirement age is one which should be left to union and management. Similarly, but for different reasons, businesses supported the position that retirement age not be increased legislatively from age 65 to age 70 , as business was wary of the increased costs to their overall employee benefit plan programs.

Generally, it can be concluded that allowing workers to remain on the job longer will reduce the real cost of a pension. However, if pension plans are to differentiate between younger and older workers, the issue of where these distinctions occur may lead to questions of a test of equal benefits, a situation that may cause employees to press for equal benefits at any age. Pensions, thrift plans or profit- 
sharing plans that give credit for service after age 65 in determining the amount of retirement income would only result in modest overall increases to the cost of pension plans. Significant costs to pension plans would result when the plans provide hospital, surgical, medical, and dental insurance, disability benefits and death benefits for older workers as the costs of these insurance programs invariably escalate when a worker reaches age 65. Costs of such insurance dramatically increase for older employees as the older worker is more likely to need the service, and in the case of death benefit insurance, a claim is a certainty at some point. 12

Thus businesses would inevitably be faced with the difficulty of restructuring their employee benefit plans, enforcing their employee appraisal systems more rigorously and providing for effective employment planning, all without the assistance of mandatory retirement. 
CHAPTER III

WHY FEWER OLDER PEOPLE WORK

The job market status of older workers is becoming an increasingly important issue in our society. The older population continues to grow in both number and proportion; in part, because of longer average life spans and lower bith rates. As the proportion of the retired population increases relative to the labor force, pressures will continue to mount on the resources of the two major retirement systems: Social Security, already strained under a sharp rise in both benefits and eligible persons; and private pensions, which have been diminished by high rates of inflation. Eventually, as the nation experiences a drop in the rate of labor force growth, more older workers may be required to remain in the labor force easing the pressures on the nation's retirement resources. 13

The labor force participation rates for older men have decreased sharply during the past thirty years, with the rate of decline increasing in recent years. The following table shows the national civilian labor force participation rates for men age 55 to 64 and 65 years of age and older, in percent: 
TABLE III- 1

CIVILIAN LABOR FORCE PARTICIPATIONS RATES:

ANNUAL AVERAGES 1

$\underline{\text { Year }}$

1950

1960

1970

1978
Age 55-64

86.9

86.8

83.0

73.5
Age 65 and $01 \mathrm{der}$

$45.8 \%$

33.1

26.8

20.5

${ }^{1}$ Percent of civilian noninstitutional population in the civilian labor force.

Source: U.S. Department of Labor, Employment and Training Report of the President, $1 \overline{979, \text { Table }} \overline{A-4}, \overline{\text { p. } 240 .}$

As the preceding table illustrates, there has been a 1ong-term decline in the participation rate of older males, particularly among males age 65 and older. The participation rate for men has fallen dramatically since 1961 when it became possible for men to retire early with actuarily reduced Social Security benefits. In 1961, the Social Security laws were amended to allow men to retire at age 62 with permanent 1 y reduced benefits, an option that had been available to women since 1956. The formula used in computing this reduction in the monthly benefit amount is a reduction of $5 / 9$ of 1 percent for each month of retirement before age 65. This means that if an individual retires and elects to receive Social security benefits as soon as he reaches age 62 , he will receive a monthly benefit amount that is 20 percent less than he would have received if he had waited until age 65 . In an attempt to reverse the trend toward ear1y retirement, Congress added, in 1976, an 
additional provision in the Social Security legislation for an increase in the monthly benefit amount of $1 / 12$ of 1 percent for each month between ages 65 and 72 for which an individual defers retirement. For those attaining age 62 after 1978 , this increment will be increased to $1 / 4$ of 1 percent. 14

Liberalized Social Security provisions have contributed to a decline in labor force participation for many workers, particularly those age 62 and older. The following table displays the significant decrease in labor force participation at age 62 , when social security benefits first become available to workers:

TABLE III-2

LABOR FORCE PARTICIPATION RATES BY AGE GROUPS

\begin{tabular}{|c|c|c|c|c|c|}
\hline \multirow{3}{*}{$\frac{\text { Year }}{1957}$} & \multicolumn{3}{|c|}{ Men } & \multicolumn{2}{|c|}{ Women } \\
\hline & $55-64$ & $62-64$ & $65+$ & $55-64$ & $65+$ \\
\hline & 87.5 & 82.9 & 37.5 & 34.5 & 10.5 \\
\hline 1960 & 86.8 & 81.1 & 33.1 & 37.2 & 10.8 \\
\hline 1970 & 83.0 & 72.2 & 26.8 & 43.0 & 9.7 \\
\hline 1975 & 75.8 & 59.7 & 21.7 & 41.0 & 3.3 \\
\hline
\end{tabular}

Source: Federal Reserve Bank of Doston, "Raising the Mandatory Retirement Age: Its Effect on the Employment of 01 der Vorkers," rune 1979, p. 24.

Since 1960 , males have left the labor force in sizeable numbers beginning at age 62 , when the previously mentioned Social security benefits first become available. This trend is clearly to be expected, as social security serves as a disincentive to work. 
When Social Security legislation was first considered in the early 1930's, prior to the passage of the social Security Act of 1935 , the country was in the depths of the Great Depression and Congress was grappling with the dual issues of increasing job opportunities for unemployed young workers, as well as with the issue of providing a retirement income for older, unemployed workers. In searching, for an appropriate model for an income maintenance program. the Congress looked to the retirement programs then available in Germany.

Nearly 100 years ago, Otto Von Bismarck, then First Chancellor of the German Empire, introduced legislation which ultimately led to the first comprehensive plan of social insurance in the Western world. Beginning in 1881 , German workers were covered under a national plan of workmen's accident insurance. In 1883, a comprehensive insurance program against illness was added, followed in 1884 by the passage of a comprehensive accident insurance program for al1 citizens. Final1y, in 1889 , a compreluensive invalidity and old-age insurance program was passed. These programs raised the need, for the first time, to define "old age". 15 Under the advice if his actuaries, Bismarck selected the age of 65 , under the assumption that since the average 1 ife expectancy in the $1880^{\prime} \mathrm{s}$ was between 40 and 45 years of age, few people would actually live to claim benefits. Great Britain passed similar legislation in 1908 , initially restricting its benefit programs to workers age 
70 or over, but later reducing the age of eligibility

to 65 .

Like the social insurance programs developed in Germany, the United states Social Security programs have developec in a pecemeal fashion, influcnced by political, economic and social considerations. The Social Security Act of 1935 was the Federal government's first attempt at income maintenance on a sustained basis. 16 The Act established retirement benefits for workers in commerce and industry (except railroads). Initially, only retired workers age 65 and older were eligible. The basis for selecting age 65 as the age of eligibility for retirement benefits was clearly an arbitrary one. In fact, former Secretary of Health, Education and Welfare, Wilbur Cohen, one of the staff who helped draft the 1935 Act has written:

"( $T$ )his brief account of how age 65 was selected in the old age insurance program in the united states indicates that there was no scientific, social or gerontological basis for the selection. Rather, it may be said that it was the general consensus that age 65 was the most acceptable age." 17 /

In 1939, the Social Security program was amended to include a 50 percent benefit for spouses, and in 1940 , compulsory coverage under the Act was extended to farm and domestic workers, farmers and other self-employed worliers. By 1056, women ares 62 to 64 bocame eligihle for reduccd retirenent bonefits and sirilar coveragc ras extcnded to men by 1261. The principal group not included in the. Social security system today are employees of the Federal 


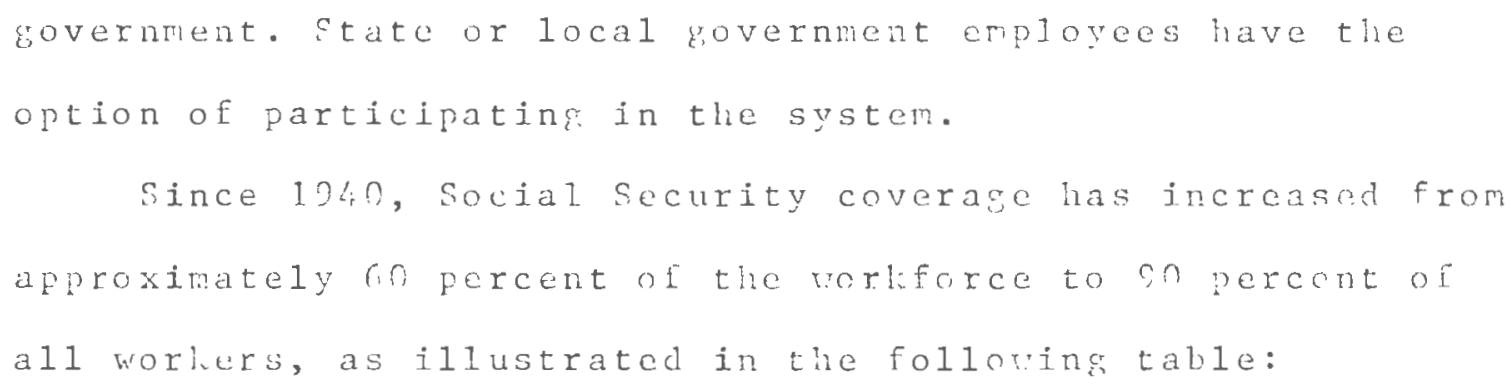

\section{TABIS: III -3}

SOCIAL SECURTTY COVERAGE

\begin{tabular}{|c|c|c|c|}
\hline ear & $\begin{array}{l}\text { Annual average } \\
\text { total paid } \\
\text { employment } \\
\text { (inthousands) }\end{array}$ & $\begin{array}{l}\text { Enployees } \\
\text { covered by } \\
\text { Social Security } \\
\text { (in thousands) }\end{array}$ & $\begin{array}{l}\text { Coverage as } \\
\text { a percent of } \\
\text { employment }\end{array}$ \\
\hline 40 & 46.400 & 26,800 & $57.8 \%$ \\
\hline 0 & 60,000 & 38,700 & 64.5 \\
\hline 60 & 67,500 & 59,400 & 38.0 \\
\hline 70 & 80,600 & 72,100 & 39.5 \\
\hline 75 & 86,200 & 77,600 & 90.0 \\
\hline
\end{tabular}

Source: Social Security bulletin: Annual Statistical Supplement, 1975. Her Publication ivo. 77-11.700, table 35, p. 68 (Vashington, D.C.: U.S. Government Printing, Office, 1977).

The dramatic rise in the number of employees covered by the Social Security Act is further complicated by a concomitant rise in the percent of eligible workers electing to retire at the earliest possible age. Simply stated, the total numbers eligible to retire at 62 is not significant in and of itself. However, since nearly half of all vorkers today are electing to retire when Social Security benefits first become available, the financial burden placed on the social security becomes readily apparent. The following table shows the dramatic increase in the percent of eligible workers electing to talie advantage of Old Age Survivors Insurance (OASI) 
at the minimum age of elicitility.

TABLE III -4

PERCENTAGE OF INSURED WORKERS $\triangle G E D \quad 62$ to 64

RECEIVING OASI BENEFITS, SLLECTED YEARS

$1957-1976$

BEGINNING OF YEAR

1957

1962

1963

1970

1974

1975

1976

\begin{tabular}{cc} 
Men & Homen \\
\cline { 2 - 2 } N/A & $16 \%$ \\
$20 \%$ & $41 \%$ \\
$29 \%$ & $45 \%$ \\
$34 \%$ & $46 \%$ \\
$44 \%$ & $54 \%$ \\
$46 \%$ & $55 \%$ \\
$49 \%$ & $56 \%$
\end{tabular}

Source: Social Security Bulletin, Annual Statistical Supplement, 1975 , Table 52, p. 85 .

Nearly al1 retirement studies confirm the proposition that higher Social Security benefits reduce labor force participation and the rapid growth and development of the system has given early retirement a powerful impetus. 18

Since Social Security benefits were originally intended to replace earnings lost through retirement and were not intended to be an old-age annuity, recipients have always been subjected to an "earnings test". In fact, the 1935 legislation denied benefits to those with any earnings. However, subsequent amendments altered the earnings test requirements. For example, in 1950 beneficiaries 75 years and older were excluded from the earnings test. In 1954, the exemption was lowered to 72 and the 1977 amendments will remove, effective 1982, the earnings test for everyone over age 70. Currently, the earnings test reduces benefits by one dollar for 
each two dollars of earnings above an exempt base of $\$ 5,000$

The earnings test, as applied to Social Security beneficiaries, also functions as a disincentive to work for retirees. Researchers have argued that the "true marginal tax rate" on earned income above the $\$ 5,000$ base is well above the 50 percent reduction in benefits, so that a "middle income worker is hit with a tax rate of over 70 percent."1?

A further incentive to retirement, and conversely a disincentive to work, concerns the method chosen by Congress to raise the benefits paid to beneficiaries. Prior to 1972 , Congress raised benefits periodically, In 1972 , Congress passed an automatic adjustment to reflect changes in the cost of living. However, this automatic adjustment plan had to be reformulated as the adjusted rate was keeping benefits well ahead of inflation. In fact, from 1965 to 1976 , the consumer price index rose 80 percent, while benefits increased 119 percent. In 1977 , Congress modified the adjustment plan to prevent adjustments from increasing faster than the rate of inflation.

Although increased Social Sccurity coverage and benefits are important, they do not fully explain the labor force trends. In addition to increases in social security coverage, disability and pension coverage has also expanded. In 1956, disability insurance was incorporated into the Social Security system, providing benefits for 
disabled workers 50 and older. Subsequent legislation added benefits for the dependents of disabled workers and in 1960 protection was extended to disabled workers regardless of age. Poor health, regardless of the cause, certainly inhibits both a worker's productivity and the range of jobs available to that worker. Nlthough the general level of health among the population is improving, as reflected in gains in the average life expectancy for all Americans, the percent of workers eligible to receive Social Security disability benefits has also been increasing, contributing at least in part, to lower labor force participation rates for older workers.

T $\triangle B L E$ I I I - 5

PERCENTAGE OF MEN RECEIVING SOCIAL SECURITY

DISABILITY BENEEITS

SELECTED YEARS - 1957 to 1972

\begin{tabular}{|c|c|c|c|c|c|c|}
\hline Year & $\begin{array}{r}\text { Are } \\
\text { White }\end{array}$ & $\begin{array}{r}5-34 \\
B l a c k\end{array}$ & $\begin{array}{r}\text { Age } \\
\text { ritite }\end{array}$ & $\begin{array}{l}35-1 \mathrm{ack} \\
\quad 13 \mathrm{ack}\end{array}$ & $\begin{array}{r}\text { Age } \\
\text { White }\end{array}$ & $\begin{array}{l}45-54 \\
\text { B I ack }\end{array}$ \\
\hline 1957 & -- & -- & -. & -- & .26 & .32 \\
\hline 1960 & .05 & .08 & .15 & .25 & .72 & 1.18 \\
\hline 1965 & .23 & .45 & .73 & 1.41 & 1.66 & 3.16 \\
\hline 1970 & .36 & .72 & 1.00 & 2.01 & 2.33 & 4.38 \\
\hline 1972 & .47 & .98 & 1.15 & 2.30 & 2.81 & 5.22 \\
\hline
\end{tabular}

Source: Frederic Siskind, "Labor Force Participation of Men, Age 25-54, by Race", Monthly Labor Review, July, I 975 pp. $40-42$.

As the above table illustrates, older vorkers are more likely to receive disability benefits than are younger workers and black males have a disapility rate nearly twice that of white males. That health should be an important 
variable in labor force participation is an obvinus, but often overlooked, one. Between 1967 and 1977 , the number of persons receiving Social Security disability payments more than doubled, with average monthly benefits increasing from $\$ 117$ million in 1967 to $\$ 752$ million in 1977.20

The growth in private pensions has paralleled the growth of the Social security system, fostered in laroc neasure by the preferential. tax treatrent of employer's pension contributions and a rise in pension-fund earnings. lorever, in recent years the private pension system has become increasingly threatened by a number of factors. Tirst, Social security payroll deductions are legislated to rise from the current 6.13 percent of a taxahte wagc base of $\$ 22,900$ to 7.15 percent in 1937 with the wage base to be icnreased automatically under the law on the hasis of the annual increase in average earnings in covered cmployment. It has becn projected that this taxable wage base vill be $\$ 42,600$ in 1987.21

Increases in the cost of Social Security naturally decrease the amount of disposable capital rorliers and employers have to invest, thereby cecreasing the attractiveness of private pension programs. Sccond, the General Accounting Office has concluded that the Employee setirement Income Security Act of 1974 (IPISA) originally enacted to protect employee pensinn plans, has actually contributed to the termination of thousands of single-employer benefit 
pension plans. The study concluded that ERISA inhibited the formation and continuation of private pension plans by increasing the employer's reporting and disclosure responsibilities, thus driving up the costs of maintaining a private pension plan.

The third and perhaps most important threat to the viability of private pension plans is the real or perceived impact of inflation. During periods of either no inflation or modest annul rates of inflation, the real value of retirement income will remain constant. However, when inflation rises, fixed income groups whose money incomes lag behind increases in prices, are penalized as their real incomes or standards of living decline. The folloving table illustrates the real value of retirement income under alternative rates of inflation:

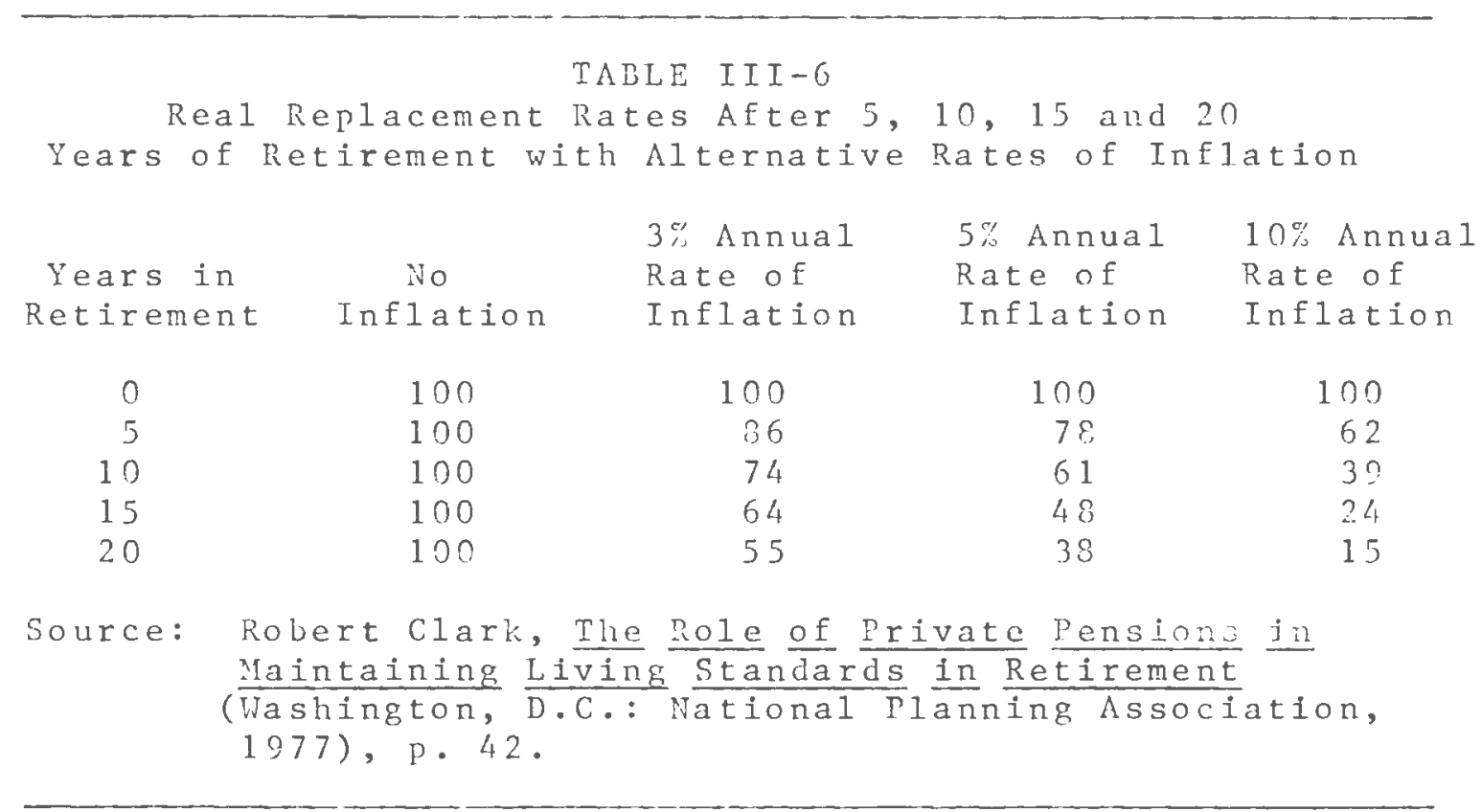


Thus, under periods of 10 percent inflation, a pension will be reduced in five years to 62 percent of its value and within seven years will be worth 50 percent of its original value. The dramatic impact of inflation on pension plans is further supported by the fact that many unionized workers have "sought job security and health and pension benefits in preference to immediate wage gains." 22

Unlike Social security benefits, which are indexed to price changes, many private pension plans do not offer automatic cost of living increases. Thus inflation, or the threat of inflation, may encourage workers to analyze their retirement decision more fully than they have in the past and more workers may elect to remain in the labor force for longer periods of time.

The preceding discussion clearly suggests that the retirement decision, like much of human behavior, is ordinarily so complex that it cannot be adequately described or measured by a single dimension. Several dimensions are usually necessary to describe or measure the retirement decision, among them the availability of pension coverage and the age of eligibility for benefits, the health of workers and their assumptions relevant to their ability to afford retirement. In addition to these factors, withdraval from the labor force is also influenced by job satisfaction, the number of dependents workers have, the type of industry in which they are employed, previous enployment experience and the level of unemployment in the local labor market.23 
The questions of whether workers rill continue to retire at the "normal retirement a to be 65 years old, or whether the trend to early retirement at age 62 will accelerate, renain constant, or be reversed, vill carry considerable impact for policymakers. The appopriate policies selected will carry considerable weight with respect to where the financial burden for providing payments to those not in the workforce will fall within society. 
CHAPTER IV

WILL OLDLR WOREERS CONTINUF TO LTAVE TIEIR JOBS

The rapid passage of the ADEA Amendments of 1978 was characterized by very little opposition in either the llouse or the Senate. In fact, when the bill was originally considered only four liouse members and seven senators voted against it. During Congressional testimony, the major focus of the testinony concerned the issue of the right of older workers to work unencumbered by an arbitrary age 1 imit. That the right to work is a civil right had been established as long ago as 1914, where in Smith v. Texas, the L.S. Supreme Court held that the meaning of liberty included the right to work. A similar conclusion was reached in Truax v. Raich (1915) where it was held that one of the intentions of the Fourteenth Amendment was to guarantee the right to work. The Fifth Amendment has also been interpreted by courts to provide the right to work on the basis that the right to obtain property assumes the ability to secure and maintain employment. Thus, the stated intent of the legislation was to remove a legal obstacle which prevented workers from remaining in the labor force as long as they were both able and willing to continue working.

The issue of the right to work as a civil right which 
should be guaranteed to all Americans ras clearly the stated goal of the legislation as expressed by both congressman Claude Pepper (D-FIa.), the llouse proponent of the bill that eventually became $l a w$, as well as by the Senate leader, Jacob Javits (D-NY). Pepper summarized his feelings by stating:

"Our findings to date suggest that mandatory retirement is discriminatory and socially unproductive. It squanders the talent of older people, and it strains an already over-burdened Social Security system, and drives elderly persons in so many instances into poverty and despair. Mandatory retirement is a cruel camoflage masking age discrimination and forced unemployment." 24

Although many of his colleagues agreed with him in principle, the question of how many older workers would choose to remain in the labor force, with the concominant ramifications on the employment opportunities of younger workers, concerned many lawmakers. In fact, Dr. Harold Sheppard, director of the Center on liork and Aging of the American Institutes for Research, testified that many European leaders were surprised that Congress was considering raising the compulsory retirement age from 65 to 70 , in spite of our relatively high unemployment, when many curopean countries wit? sit ilar unemployment rates were considering lowering their retirement age to 60.25 Upon further questioning by Representative Russo (D-I11.), Dr. Sheppard provided an answer typical of many of the witnesses:

Mr. Russo: We have a problem (unemployment) right now. Do you have any suggestions?

Dr. Sheppard: He have a big youth employment program. Let's give it some support. We have a new proposal to give incentives to the private sector to hire more youn rith certain tax credits or other linds of incentives. Let's 
make sure they do that.

There is also a very unsettled issue in the field of labor economics. There is one argument that says there is the fixed lump of labor supply and only so many jobs can be handed around.

The other argument is that if you in some way get more people employed in the labor force, you get an increase in the purchasing porer, which increases the derand for more people to be hired.

I frankly have to say I don't know which one is rimt. I don't lile the first one. That is all I can say. It minht be just a viseral reaction. It is a vay of not meeting the problem. 26

Dr. Sheppard's comments reflect the vievs of mary ritnosses who testified before the llouse Comitten on hrinr and tive Subcomittce on netirement, Incone and rmployment. Comprehensive evidence, sucl as that found in rany fornal studies, was not available. Instead, vitnesses reliod on older studics or public opinion polls in assessing tre impacts of increasine the age of mandatory retircment. Tor example, many witnesses and at least one Congressional "orking Paper cited a 1974 larris Poll, conducted for the liational Council on Aging, Inc., that found over io percent of those surveyce arreed tiat "nobody should be forced to retire because of are, if he wants to continue working and is still able to do a rood jol."27 wie warris study projected that there were alout 2 nillion unemployed or retired older jersons vho voule lite to wor... Lowevcr, tibs cotirate was considered to draratically overstate tie number of older vorlers that woull he interested in remainini in the labor Eorce. 
Senator Iell asied tile employment cuesiton of nonald

Elisburo, Assistant Secretary for Imployment Standards,

Department of Labor:

Senator pell: If this legislation passed, what would be the impact, do you thint most rorliers would stay on until they are 70 or 63 ?

Mr. Elisburg: Vell, Senator, we have estimated that perhaps 175,000 workers might be involved.

Senator Pell: In the whole United States?

Ir. Elisburg: The effect on employment, from some preliminary studies, of age 65 to 70 , would be a labor force impact of approximately two tenths of 1 percent for men and one-tenth of 1 percent for women based on those reaching age 65 who would prefer to stay on the job. It is reasonable that large numbers of employees who would normally be eligible to retire at age 65 would continue to retire at age 65.28

In preparing this estimate, the Department of Labor relied on two documents: (a) the Social Security Administration's Survey of Newly Intitled Beneficiaries (SiJB), and, (b) the Current population Survey (CPS), conducted by the Bureau of the Census.

The Survey of Newly Entitled Beneficiaries (SicB), conducted by Virginia $P$. Reno in March 1972 , indicated that 11 percent of the men and 7 percent of the women in the sample would have chosen to continue working heyou. $t^{\circ} \cdot x$ compulsory retirement afe. When the CPS Report's population projections are combined with 1970 labor force participation rates for 64 year olds, there would be an estimated 2,483,000 men and $1,458,000$ women aged 65 to 69 in the 1 abor force in 1985 . If the increase suggested by the SNEB of 11 percent for men and 7 percent for women was calculated, the labor force would be increased by 273,000 men and 102,000 women, accounting for 
an increase of .35 percent.29 This estimate was considered excessively high, as it assumes that everyone who wanted to work past age 65 would continue to work until age 70 .

The Department of Labor submitted written comments in answer to Senator Pell's question and stated that "a judgemental figure of 200,000 was arrived at by considering the estimated number of workers involuntarily retired through pension plan requirements or other reasons."30 other evidence in support of this conclusion was offerred by the Department of Labor which observed that the "U.S. labor force does not expand on a one-out, one-in" basis. 31 The Department noted that industries and firms experience different economic conditions and will respond by increasing or reducing their labor force as needed. Thus, because a worker retires, there is no automatic movement to hire a new worker, as employers may be reducing their workforce through attrition. Conversely, some employers may be expanding their workforce even though no workers are retiring. The Department concluded that the fact that older workers remain in the labor force cannot be considered an obstacle to entrance into or mobility within the labor force for younger workers.

The Department also concluded that historical trends tovard early retirement were not likely to be reversed in the shortrun anc that Social Security and private pensions werc porerful disincentives to work. These trends, already noted in the preceediner chapter, existed across the board for both salaried and hourly omployecr in all industries and it vas reasoncd that 
older employees, as long as they remained productive, should not be forced out of the workforce to make room for younger workers. The Department sumarized its conclusions by stating, $"(0)$ ne cannot program the older vorker to a reduced retirenent income and inactivity as the means to achieve promotion for others. This would be rotbing one generation to pay another."32 other testimony before the liouse Select Comittee on Aging from various representatives of corporations clearly supported this view. General Motors and the Ford ifotor Corporation indicated that only 2 percent of hourly workers worlied until the mandatory retirement age of 63 and that 39 percent of their employees retired before age 65. Exxon reported that about one out of five employees waited until the mandatory retirement age of 65 to retire and General Foods reported a similar percentage of workers retiring at the mandatory retirement age. Representatives from IBM claimed that since 1970 , fewer than 20 percent of its 7,000 retireees waited until age 65, and in 1976,34 percent of its employees retired before age 65 .

In sumary, testimony before Congress from industry representatives, researchers and the Department of Labor supported the trend toward early retirement and offerred no conclusive evidence that the impact on job opportunities for younố workers would be extensive.

At this point it should be noted that the studies cited in the literature, as well as in Congressional testimony, concerning the impacts of increasing the age of mandatory 
retirement shared a number of similar characteristics. Like the study conducted by Reno, much of the information was dated. For example, a study conducted by Herbert Parnes at Ohio State University, "The Pre-Retirement lears: A Longitudinal Study of the Labor llarket Experience of Men," was completed in 1971 and concluded that about $\delta$ percent of the men surveyed who were mandatorily retired wanted to work longer. The Parnes' study used the worker as the "unit of analysis," as did the Reno study. Although testimony from representatives of major corporations was heard, there were no studies which used the employer as the "unit of analysis," and if such research had been available, it would have offerred a valuable perspective on the question of the impacts of increasing the age of mandatory retirement.

Ilowever, since the passage of the 1978 Amendments to the ADEA, at least two additional studies have been completed, one by Portland State University researchers Lois Copperman, Douglas lontgomery and Fred Keast, and another by researchers at the Bureau of National Affairs (BHA). The Portland State researchers, using both mail and telephone survey approaches, were able to obtain surveys from nearly 2,000 firms for their 1979 study. While the study examined the potential impact of the amendments on the employment opportunities of women, youth and minorities, it also considered the impact on pension systems, the probable impact os ir lation on pensions, and the possible extension of worklife for older workers.

One of the major findings of the Portland state study was 
that employers did not expect historical trends toward early retirement to be reversed. 33 However, employers believed that continuing, high rates of inflation would alter worker's perceptions of the desirability of early retirement. The researchers belicve that, in the long run, labor force participation rates for older workers would increase and that by the year 2000 firms will be increasingly more reliant upon older workers, suggesting that the key issue in labor recruitment will be the "selective retention of those who could realistically choose to end their work 1 ife." 34

A second major conclusion of the study, and in many ways related to the preceeciing observation, will be the increasing inportance of an cmployer's performance appraisal system. Yith the increase in the age of mandatory retirement, rarrinally procuctive worlers, who would have been retirec uncer tie former arc cojing of 65 might want to worl until ae 70 . nusinesses would be faced vith tive decision of allorins a marsinally productive older vorler to continue torling or to terminate that employee. mile firms may have been rillins to alsow a marginally productive 64 year old cmployee to work one more year to age 65 , it is unlikely that firms will allow unproductive older workers to work until they are 70. Therefore, it is cuite likely that personnel appraisal practices will becin to esamine productivity of older vorliers more critically. If this opservation is accurate, it rould represent an ironic trist, as tide overriding concern of the legislation ras to encourage the participation of older worlers ia the rurlaforce. 


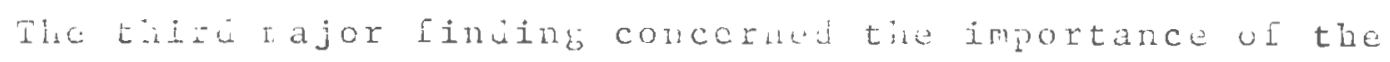
size oi the Eirn to the applicability of the Abra amendments. Zaspondents resesenting firms of over 250 employecs almost universally acknowlerged tive legislation's direct aprication to tirir companies, wille those respondents representing smaller firms, especially those with fewer twan 100 employees, saw their companies as beins affectcd with less Erequency. Altiough the survey results did not, in general, suggest that firms expected the MDEA Amendments of 1978 to liave a major impact, the cffect of the ADEA Amendments was expected to be greatest for certain sectors of the economy, as well as by firm size.

Perhaps tine most important conclusion of the study, at least in terms of its implications for Rhode Island, concerned the impact of continued high rates of inflation on the retirement decision of workers. Responses from liew Ingland indicated that nearly 43 percent of the firms surveyed believed that under continuing high rates of inflation, workcrs would most likely remain in their jobs past the normal retirement age. 35 The frequency of this response was predicted to be fully 30 percent above the national average. To the extent that the Rhode Island economy mirrors the ver. England economy, the long-term implications on employment prospects, in terms of both internal mobility and job opportunities, could be severe. However, in an extensive analysis of the inflicice of the ADEA on job opnortunities for women, youth and minorities, the study concluded that the larger the size of the establishment, the more likely employers are to vicw the amendments as 
reciucing job opportunitias for these froups. Thus, in the immediate future, the study concluded that the larger firms, because the "criteria for hiring tonds to be more objective and impersonal than those of smaller firms" are likely to retain older workers. 36

In attempting to guage the implication of the conclusion contained in tile study for the Rhode Island lator force, one final conclusion must be highlighted. In general, the researchers found that tile older the labor force, the less 1 ihely the arenclments were viewed as reducing job opportunities for youth, millorities and romen. However, as the proportion of "riddleaged" workers (ages 40-59) increased, the amendments were vietred as reducing job opportunities for botn women and minorities. Tinis conclusion suggests that firms with older workforces fully expect these older workers to retire, thereby creating employment opportunities within the firm and that the "younger" the workforce, that is, those firms which have few workers of retirement age, expect to see fewer job opportunities. While this conclusion seems obvious, it does suggest that many employers foresee a period of slow economic growth where there will be fever job opportunities as a result of conditions within the economy and not as a result of policy changes in tire age of retirement.

The second recent study, conducted by the Eureau of ilational Affairs (BiA) in August 1979, involved a survey of 267 organizations. In this survey, the ill solicited the opinions of personnel representatives from hoth large and 
small firms involved in manufacturing, nonmanufacturing and nonbusiness organizations. Ifore than 51 percent of the employers reported "very little impact" from the changes in the ADCA legislation, with another 35 percent "fecling no impact."37 However, 21 percent of the employers did find an increase in the number of employees electing to postpone retirement past the "normal retirement age." liany of the respondents were unable to specify the exact increase, although a number did describe it as "slight, minute, small or minimal."3r. Two survey participants reported more detailed findings, as a Minnesota medical center claimed "100 percent of those eligible to retire at 65 have elected to stay on at least part-time," and an eastern government agency reported that of those now retiring, "5 percent" are older than 65 years of age. 39

The survey confirms the findings of the researchers at Portland State university, and the testimony of Congressional witnesses relative to the initial impact of the legislation. Although few retirement age workers are remaining in the labor force, the BNA study found many employers still feel the overall impact of the legislation is yet to be determined. Perhaps the most immediate impact has been on the personnel departments of many large firms now faced with a need to determine the individual retirement decisions of workers, as well as to develop more complete performance appraisal systems. The Bis survey identified a wide range of responses to the approaches of many firms on the adjustments that many companies are making to accomodate their older vorkers. 
The policy implications of nost legislative actions are difficult to completely anticipate. Social le:rislation, by its very nature, is complex to evaluate because it seelis to change behavior. Vieved within this context, social lerislation vill usually stand in direct contradistinction to many existing; traditions currently embraced throughot society. clearly, the historical forces torard early retirement, which have virtually made carly retirement a social goal, vill not be completely reversed in the short run.

The rotirement decision is a very complex and personal decision for both employers and employees. 'Thile a worlior's

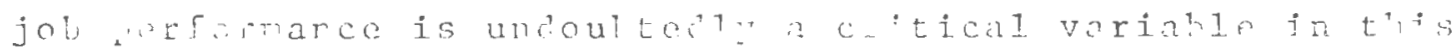
relationship, a torler's financial resources are no less inportant. Yistorical patterns tourd early retirement have develonec during an ora characterized by increases in vorter productivity and lor rates of inflation. Tn essence, these Forces are closely intertrined in a connlex set of relationships only briefly delineated in this paper.

whe research objectives that ruided this policy analysis were intwrod to neasurs the short-term inasts of the logislation on joh rohility for pouncer rorkers, romen and 
minorities and to measure tho iong-term impacts on tho retirenut decision of roriers uncer the assumption of continuing high rates of inflation. To accomplish these objectives, a mail survey was conducted of $10 \%$ manufacturing firrs located in the state of linocie Islanu. The sariling plan involved a stratifiea sampling methodology of firns involvad in tio procuction of goods from SIC Cole 20 to 35 , cxilucing $I C 21$ anci 29 . (See Appendia $\Lambda_{2}$, survay Instrulent, Jntroductory Fostcarc, Introuctory Letter are Tollot.u Leter)

Tie survey instrument was abinistered during tive ront: of Feuruary $19 u 1$ using the three-step rethorology delineatca in sppencix is. (Sec Appendiz j, Survey lietrodology) sbout one wer after the post cards tere nailed, the surveys rere sent out. During tie third reek, the followp letter vas mailed, extending the survey schedule to three weelis. Results were then punched onto cards and tabulated using the statistical Tackage for Social Scientists (SPSS).

The response rate for the survey ras cxcellent. of the 107 surveys mailed, 33 were returned proviaing a 79 percent response rate. The high response rate for this survey, rhile difficult to precisely identify, seems attributalle to the methodology employed as well as to a particularly fortunate event. During the week the surveys were mailed, "The Providence Evening Dulletin" ran a Eront page article (February 12, 1931) entitled "Handatory Pension Plans, older Retirenent Report" which aiscussed the findings of the President's Commission on Pension Policy and lighlighted the proposed changes 
in retirement policy. Althourh it is difficult to measure the influence of such an unanticipated event, the article is mentioned because it may have contributed to the high response rate.

The responses displayed in the following table indicate that four SIC codes $(20,26,23$ and 39$)$ reported 100 percent coverage as al1 six (6) firms in those industries returned their surveys. iro SIC code reported under 3 ? ircent coverage. The firr:s included in the sample employed over 12,400 people or approximately 10 percent of the total manufacturing workforce of Rhode Island.

TABLE $\quad V-1$

Completed Surveys by SIC Code

$\underline{\text { SIC }}$ Iitle

Food and Kindred Products Textile "ill Products Apparel and Other Textile Products Lumber and Wood Products Furniture and Fixtures Paper and Allied Products Printing and Publishing Chemicals and Allied Products Rubber and Misc. Plastics Products Leather and Leather Products Stone, Clay and Glass Products Primary Metal Products Fabricatcd lieta 1 Products Machinery, Except Llectrical Electric and Electronic Equipment Transportation Equipment Instruments and Related Products Miscellaneous ifanufacturing

\section{$\underline{\text { SIC }}$ Code}

20

22

23

24

25

26

27

28

30

31

32

33

34

35

36

37

38

39
Completed

Surveys

\section{6}

\section{4}

$$
4
$$

Tota 1 
Ferhaps the most significant observation that can be made about the survey respones is that there was a remarkable homogeneity in the distribution of much of the information. The following table clearly illustrates this point, as there was virtually no difference in the responses to the survey by small, medium and large firms. While the original sampling plan was designed to include one-third of the sample from small, medium and large firms, the survey results closely parallel this uistribution.

TABLE $\quad \mathrm{V}-2$

Average Employment of Surveyed Firms $\underline{\text { Firm Size }}$

ivumber

25

31.

27 83
Percent $30.1 \%$ 37.4 32.5

Total

Firms employing, 100 or more workers represented noarly one-third of the total sample, vhile small firms employine, between 4 and 19 workers represented a slightly smaller total. Firms with 20 to 29 vorliers represented the greatest number of survey responses. Thus, the distribution of survey responses closely parallels the original sampling plan without a great deal of variation.

The distribution of firms by the number of vears they have Leen in business displays more variation. As the next table illustrates, firms with less than 5 years in iusiness represent 
tile srallest proportion, as only 4 percent of the total is comprised of this group. The largest group, comprising

alnost one out of three firms, was represented by firms with

between 26 and 50 years in business. This question vas

included with the expectation that it would serve as an incicator of the age distribution of the labor force of the firms included in the sample.

\section{TABLF $\quad V-3$}

Years in Dusiness for Surveyed Firms

$\begin{array}{lcc} & \text { ijumber } & \text { Percent } \\ \text { 1ess than 5 years } & 3 & 3.6 \% \\ 6 \text { to } 10 \text { years } & 12 & 14.5 \\ 11 \text { to } 25 \text { years } & 27 & 24.1 \\ 26 \text { to } 50 \text { years } & 27 & 32.5 \\ \text { more than 50 years } & 20 & 24.1 \\ \text { Vo response } & 1 & 1.2\end{array}$

Total

33

The information presented in Table $V-3$ shows that 47 firms or 57 percent of the sample have been in business for more than 25 years, suggesting that the sample contains a significant number of firms which should also have large numbers of older workers.

Table $V-4$ displays information with regard to the past policies on mandatory retirement for the firms included in the sample. As the table illustrates, nearly lo percent of the firms in the sample had a mandatory retirement age for employees. 
TABIE $V-4$

:andatory Retirement Policies

Question: In 1977, did your firm have a mandatory retirement age for any of its workers?

$\begin{array}{lcc} & \text { iivmber } & \text { Percent } \\ \text { Yes } & 13 & 15.7 \% \\ \text { ivo } & 70 & 84.3\end{array}$

Total

83

Significantly, mandatory retirement policies are strongly associated with the size of the firm's workforce. While this may seem an obvious conclusion, the firms included in the sample clearly show that as the size of the firm increases, the incidence of mandatory retirement age policies also increases. The following table shows the relationship between the size of the firm and the incidence of mandatory retirement policies.

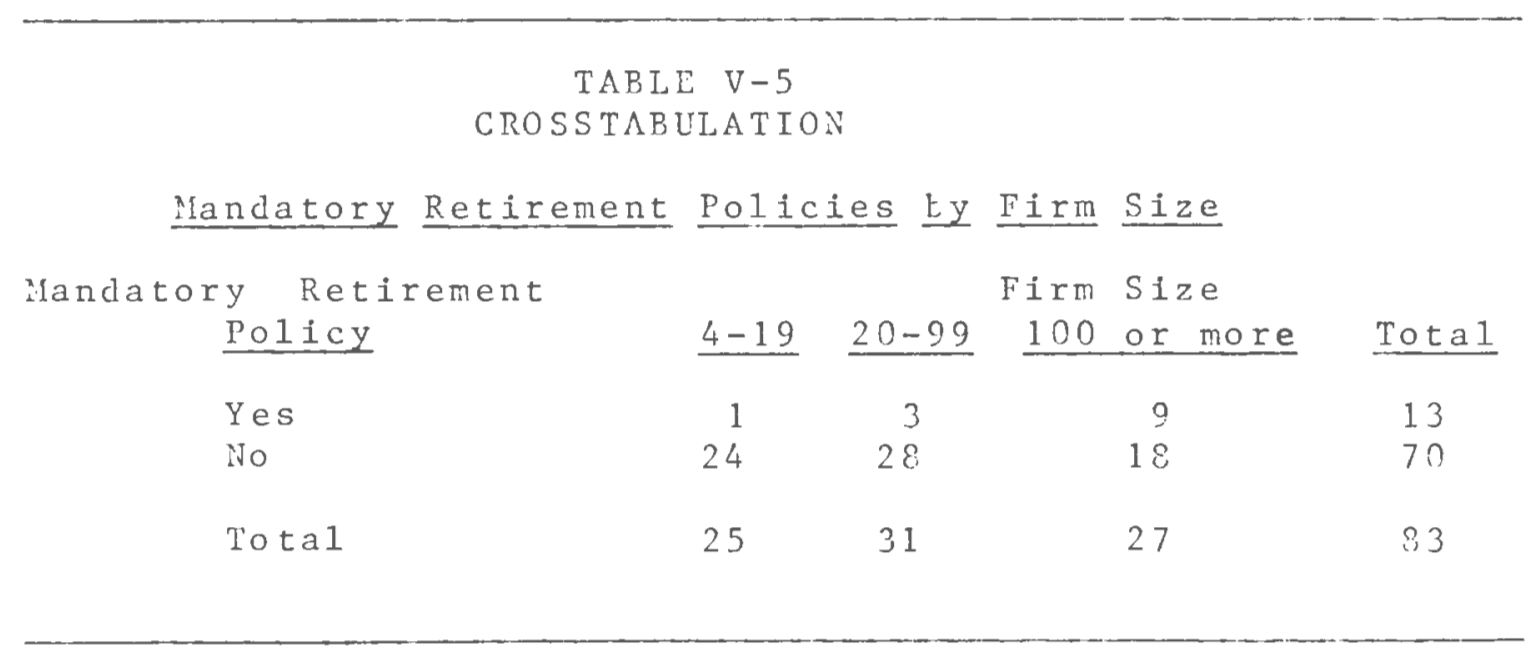

Note: $x^{2}=0.79 *$

*Significant at .01 
Additional analysis of the distribution of mandatory retirement policies by firms procucing durable goo:"; (CTC $\therefore 2,25$, and 32 througi, 39) and non-durable goods (SIC 20 , 22, 23 and 26 through 31) did not indicate any relationship between mandatory retirement policies and these SIC categories.

Retirement age policies were applicd to both white collar workers and blue collar vorkers, although three respondents with nandatory retiremert age policies did not subject white collar workers to the same retirenent policies as were blue collar vorkers. White collar workers were most likely to be madatorily retired at age 65 , evidence of the institutionalization of age 65 as the normal retiremert are.

TABLL V $V-6$

netirement Age for White Collar Worlers

nuestion: $\Lambda$ t rhat are rere white collar worlers mandatorily retired?

$\begin{array}{rrr} & \text { Yumber } & \text { Percent } \\ \text { Age } 65 & 1 ? & 77 \\ \text { Yo retirenent age } & 3 & 23\end{array}$

Total

Retirement are policy for white collar worlors ras

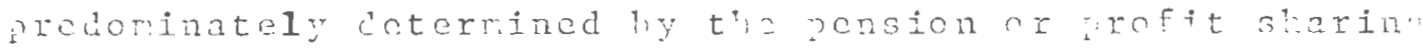
ara offorrot by the conany or ly company poljcy. Melatively Eel witc collar rorlers rore subject to a mandatory retirewent policy that ras collectively larrainec, n riading consistent with the fact that rany wita collar rortars are 
not unionized.

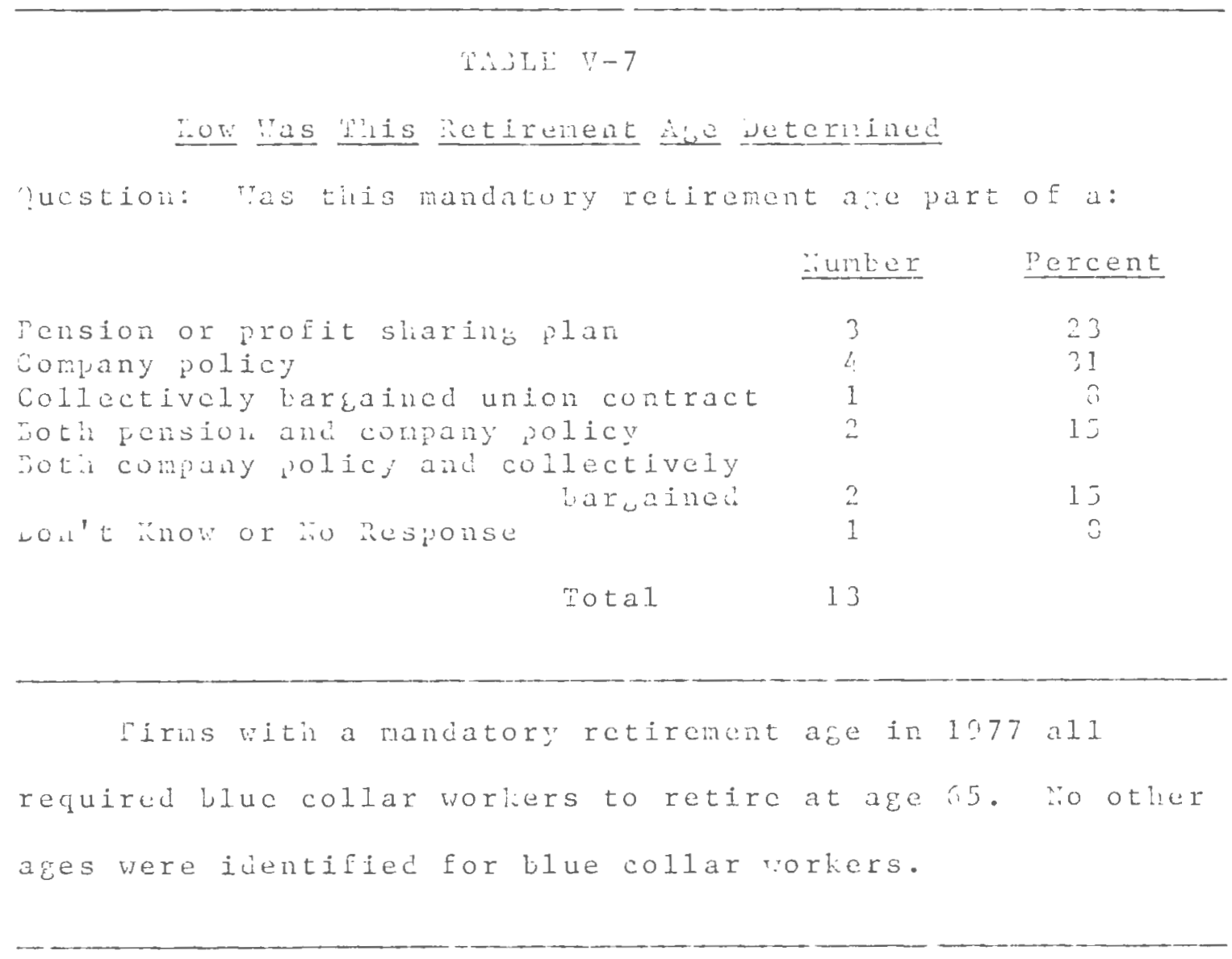

TADLI: V-S

Retirement irge for Elue Collar rorbers

Question: At what age were bluc coilar workers mandatorily retired?

$\begin{array}{lcc} & \text { Number } & \text { Percent } \\ \text { Age } 65 & 13 & 100 \\ \text { Other ages } & 0 & 0\end{array}$

Total 13

In addition to not having an alternative retirement age, blue collar workers were also more likely to have had their rctirement age establisled as part of a collectivcly barsained 
union contract. The followinc table indicates hov the retirement açe for blue collar workers vas established.

TABLE V-9

Ilow Was This Retirement Age Deternined

Question: Vas this mandatory retirement age part of a: iumber Percent

Pension or profit sharing plan Company policy

Collectively bargained union contract

Doth pension and conpany policy

323

$4 \quad 31$

431

$2 \quad 15$

Total

Since the passarc of the ADLA Amendments of 1973, firms which previously had mandatory retirement policies have modified their retirement policies. As might be expected, most firms simply substituted age 70 for age 65 . The following table displays information on hov the firms surveyed responded to the changes legislated in 1978 .

\section{TABLL V -10}

liow Firms llave Modified Their Retirement Age

Question: How have you modified, or how do you intend to modify the mandatory age in order to comply with the clianges in retirement age policy? Ilave you or will you:

Number

Percent

Increase to age 70

Increase to past age 70

Abolisin it entirely

Leave the agc unchanged

iNo Response

9

0

Total
70

0

8

3

15 
Nearly 70 percent of the firms with a mandatory retirement policy simply increased the age of retirement to 70 years of age. Only one firm completely abolished the are and one firm, in apparent violation of the lav, has not changed its nandatory retirement age.

Significantly, a majority of firms with a nandatory retirement age policy believe that employees would choose to work past age 65. Nearly 70 percent of the firms believe that some employees vould extend their worklife, as displayed in the following table.

\section{TABLE V-1 1}

Do You Expect Employees to Vork Past Age 65

question: In the next few years do you expect any of your employees to choose to work past the age of 65 ?

$\begin{array}{lcc} & \text { Number } & \text { Percent } \\ \text { Yes } & 9 & 70 \\ \text { No } & 2 & 15 \\ \text { Not Sure } & 2 & 15\end{array}$

Total 13

Then questioned further about whether any specific group or groups of employees rould be more likely to ror: longer, employers responded with less certainty. The folloring table sumarizes the responses of employers to the question of whether certain groups of employees will work longer. 


\section{TALLE V-12}

Vill Certain groups iorl Longer

Question: 2o you expect any particular «roup of your enployees to worl. longer than otier groups?

\begin{tabular}{|c|c|c|}
\hline & liumber & rercent \\
\hline Yes & 6 & 46 \\
\hline & 4 & 31 \\
\hline ot Sure & 3 & 23 \\
\hline
\end{tabular}

Total

13

Significantly, no responaent felt that blue collar worlers, cicfined as craft vorlers, laborers, operatives or service vorkers, were likely to extend their worklife. This is significant because in manufacturing industries, the majority of the workforce is employed in blue collar occupations. llowever, wilte collar vorkers, particularly executives, were expected to continue working past age 65. Other groups of employees were expected to renain in the vorkforce and the following table displays the expected distribution.

\section{TABLE V -13}

Groups Expected to Remain in the Norkforce Past Age 65 Ouestion: Which particular group do you expect to worl 1 onger?

\begin{tabular}{|c|c|c|}
\hline & iumber & Percent \\
\hline Executives & 3 & 37.5 \\
\hline iianagers & 1 & 12.5 \\
\hline Technica1 workers & 0 & 0 \\
\hline Clerical workers & 1 & 12.5 \\
\hline Blue collar workers & 0 & 0 \\
\hline Executives and sales workers & 1 & 12.5 \\
\hline Tecinical and clerical workers & 1 & 12.5 \\
\hline
\end{tabular}


Generally, respondents belleved that white collar workers were more likely to remain in the workforce for longer perlods of time. Again, this conclusion could have been anticipated as white collar jobs are generally less physically demanding than are many blue collar occupations.

In contrast to the 13 firms that had a mandatory retirement age for their employees in 1977,70 firms did not mandatorily retire workers. In fact, 50 ftrms or 71 percent of those firms without a mandatory retirement age policy in 1977 indicated they previously had workers remain past age 65. The following table illustrates the distribution of firms which did not mandatorily retire workers.

\section{TABLE $\quad \nabla-14$}

Firms Which Allowed Workers to Work Past Age 65 Question: Have you previously had any employees work past age 65 ?

\begin{tabular}{lrr} 
& Number & Percent \\
\cline { 2 - 2 } Yes & 50 & 71 \\
No & 17 & 24 \\
Not Sure & 1 & 1 \\
No Response & 2 & 3
\end{tabular}

Total 70

A significant number of firms had neither a mandatory retirement age policy nor any experience with workers remainIng in the workforce beyond age 65, suggesting the powerful Influence of age 65 as the normal retirement age for workers. The information in the above table clearly supports the long- 
term trend for workers to leave the labor force at age 65 , as nearly one firm in four, without the artifical constraint of a formal retirement age, has not had any workers remain past age 65 .

When the employers who did have workers remain past age 65 were asked to indicate what percent elected to work 1 onger, fully 70 percent claimed that no more than 10 percent remained past age 65. The following table 11lustrates the distribution of workers that have remained past age 65 .

TABLE $\quad \mathrm{V}-15$

Percent of Workers Age 65 Who Have Kept Working Question: Approximately what percent of your employees who reached 65 elected to work longer?

$\begin{array}{llrr}1 \text { to } 10 \text { percent } & \text { Number } & \text { Percent } \\ 11 \text { to } 25 \text { percent } & 35 & 70 \\ 26 \text { to } 50 \text { percent } & 2 & 4 \\ 51 \text { to } 75 \text { percent } & 3 & 6 \\ 76 \text { to } 100 \text { percent } & 1 & 2 \\ \text { Don't Know } & 3 & 6 \\ \end{array}$

Total 50

Interestingly, some employers indicated that workers in certain specialized crafts, such as molder and coremakers, were encouraged to work longer because it was difficult to find younger workers with equivalent skills. Other employers noted that many older workers have better work habits and productive capability than do younger workers and these older workers are encouraged to remain as long as they are physically 
capable of vorking. The f. firms that indicated that between 76 and 100 percent of their workforce had remained past age 65 were closely examined but did not display any distinctive characteristics that would help explain why such a large percentage of workers remained past age 65.

When employers vere asked whether any group of their workers would remain in the workforce past age 65 , they responded with a comparable but higher percentage distribution than dici employers that did not have any torkers renain ": aud 65. As indicated in t:a Following table, 46 percent of employers with a mandatory retirement policy helieved that certain groups would remain in the worlforce. The next table illustrates how employers who did not have a mandatory retirement policy and, hence, have had experience with workers remaining past age 65, expect workers to participate in the labor force.

TABLE $\quad \mathrm{V}-16$

Will Certain Groups Work Longer

Question: Do you expect any group of your employees to want to work longer than others?

$\begin{array}{lcc} & \text { Number } & \text { Percent } \\ \text { Yes } & 31 & 44 \\ \text { Wo } & 34 & 49 \\ \text { iot Sure } & 5 & 7\end{array}$

Total $\quad 70$

As the table illustrates, 44 percent of employers without a mandatory retirement age for their workers expect certain 
groups to remain in the workforce. Then combined with the information provicled by employers that had a mandatory retirement age policy, nearly 45 percent of all employers expect some workers, as a droup, to remain in the labor force beyond age 65.

In speculating which groups of workers would be expected to work longer, employers vithout a mandatory retirement age policy fully anticipate that executives would most lilely want to remain past age 65. This conclusion is consistent with the expectation of firms which did have a mandatory retirement age policy. While the 1978 ADEA Amendments required mandatory retirement at age 65 for chief executives of a company, specifically those in the upper echelons eligible for an annual pension in excess of $\$ 27,000$, not all executives are affected. Thus, the finding that many executives will remain past age 65 is considered significant as competition for these positions from younger workers is likely to intensify in the years ahead. The following table shows the frccuency with which respondents predicter that exccutives wnul" rorl: past age 65 . 
Croups rapected to Renain in the rortiforce rast tre 65 Question: Which particular group do you expect to vork loner?

Number Percent

Lxecutives

Clerical workers

ilue collar workers

Sales worliers

Lxecuzives, nanagers anb techical

ixccutives, maragers, tccinical and

Iiecutives, nanarers anu sales

Ixecutives and managers

Executives and blue collar wortiers

ilanayers and bluc collar woriters

ínagers, tecinical, clerical alid tIue

A11 worivers clerical

7

$6 \quad 17 . ?$

$12 . ?$

$2 \quad 5.7$

$3 \quad \therefore .5$

12.

$6 \quad 17 . ?$

12.8

12.3

$\operatorname{col} 1$ ar

Tota 1

In adution to tile large number of responses predictins that crecutives will worl. past are 65, manarers, technical worliers and clerical workers are all expected to rorli past age 65. Significant numbers of blue collar worlers are expected to remain in the worliforce, unlike the finding of employers with retirement age policies, possjbly a result of the fact that employers wio did not ilave a mandatory retirement age policy have had experience rith older worliers remaining past age 65, and are in a better position to identify will groups of worliers are likely to remain past age 65. When talien together, 42 enployers or appoximately 51 percent of all those surveyed Eelt that some groups of 
employees wore lihely to renain in the workforce past age 65

The foregoing questions were primarily concerned with identifying the previous experience employers have had with mandatory retirement policies. The next section of the questionairre astied employers to estimate tive irpacts they expected from the changes brought about ry the 1978 ADCA Amendments and their opinion of the proposed changes.

Employers were first asked whether mandatory retirerient will be abolisied nationally, in an attempt to guage both their expectations about the future of mandatory retirement and the potential impacts of increasing the are beyond are 70 .

TALLE V-13

Will Mandatory Retirement lie Abolished

Question: Nationally, do you expect mandatory retirement to be abolished entirely?

$\begin{array}{lcc} & \text { Tercent } \\ \text { Yes } & 45 & 55 \\ \text { iro } & 26 & 32 \\ \text { irot Sure } & 11 & 13 \\ \text { iro Eesponse } & 1 & 1\end{array}$

Tota 1

33

As the table illustrates, over 50 percent of all employers believe that mandatory retirement will be abolished. When combjned with information from the next table, it can be concluded that not only do the majority of enploycrs expect randatory retirement to be aboljshed, but they so 
not expect the abolition of mandatory retirement to have a significant impact on their firm.

\section{TALLF. V-19}

\section{Affect of fuolis"ins "andatory petirement}

nuestion: If the mandatory retirement age werc to be abolished entirely, what affect would it have on your company?

\begin{tabular}{lcr} 
& Percent \\
\cline { 3 - 3 } Great Affect & 2 & 2.4 \\
Moderate Affect & 5 & 6.0 \\
Some Affect & 8 & 9.6 \\
Little Affect & 26 & 31.3 \\
No Affect & 35 & 42.2 \\
Don't Know & 7 & 8.4
\end{tabular}

Total

Only 13 percent of the respondents believed that alolishing manciatory retirement would have any substantial impact on their companics. The overwhelming majority believe that removing the uper limit for vorkers rould have little or no ingact on their. company. To a large extent, this conclusion is supported by the fact that relatively few firms ( 13 or lf porcent) had a mandatory retirement age policy in 1077. Thus, "uncanning" the are of retirement does not pose any substantial threat to most employers.

Liovever, firns with a mandatory retirement age in 1977 roro more likely to predict that abolishin: mandatory retirement would have a simificant impact. This could have heen nnticipated, as tiose firms wit: a monotory retiranent as,e save not

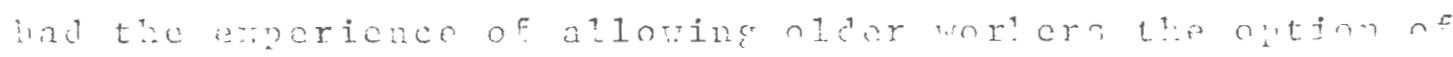


working longer. Thus, they are not sure of what the demand to work longer will be. The next table displays this reIationship.

\section{TABLE V-20 \\ CROSSTABULATION}

Retirement Policy by Affect if Abolished

Mandatory Retirement
Policy
Affect if

Abolished

\begin{tabular}{lcc} 
& $\begin{array}{c}\text { Greet, Moderate } \\
\text { Some }\end{array}$ & $\begin{array}{c}\text { Little, None } \\
\text { Don't Know }\end{array}$ \\
\cline { 2 - 3 } Yes & 7 & 6 \\
No & 8 & 62 \\
Total & 15 & 68
\end{tabular}

Note: $\mathrm{x}^{2}=13 \cdot 32 *$

*Significant at .01

In attempting to guage the age of retirement for both white collar and blue collar workers, and therefore the potential impact of abolishing the age of mandatory retirement, respondents were asked to indicate what percent of white collar and blue collar workers retire before age 65 . Over 5 out of every 8 employers claim that less than 10 percent of their white collar workers retire before age 65 . While nearly 25 percent of the respondents were unable to provide an estimate to this question, it seems clear that relatively few white collar workers retire before age 65 . 
TATLL. $Y-21$

Hite Collar Vorhers tiat Retire Defore Age 65

nuestion: Regardinn employees wo presently retire prior to age 65, approximately what percentare of your wite collar (professinnal, technical, rianagers and achinistrators, sales worlers and clerical) vorlers retire prior to ace bj?

\begin{tabular}{|c|c|c|c|}
\hline & & Innber & Percent \\
\hline STone & & 38 & 45.8 \\
\hline $1 \mathrm{tc}$ & 10 percent & 18 & 21.7 \\
\hline $11 t$ & 25 percent & 3 & 3.6 \\
\hline 26 tc & 50 percent & 4 & 4.5 \\
\hline $51 \mathrm{tc}$ & 73 percent & 0 & 0 \\
\hline $76 \mathrm{tc}$ & 100 percent & 1 & 1.2 \\
\hline Don't & Know & 19 & \\
\hline
\end{tabular}

Total

33

In contrast to the distribution of retirenent are

for white collar workers, blue collar vorkers are more likely to retire before age 65 than are rhite collar vorlers.

\section{TARIL $V-22$}

Blue Collar Morkers that Retire Defore lis s?

Question: Regarding your blue collar workers (craft workers, operatives, laborers and service workers) what percentage retire prior to age 65 ?

\begin{tabular}{|c|c|c|c|}
\hline & & Number & Percent \\
\hline None & & 26 & 31.3 \\
\hline 1 tc & 10 percent & 22 & 26.5 \\
\hline $11 t c$ & 25 percent & 5 & 6.0 \\
\hline $26 t c$ & 50 percent & 5 & 6.0 \\
\hline $51 \mathrm{tc}$ & 75 percent & 4 & 4.3 \\
\hline 76 tc & $100^{\circ}$ percent & 3 & 3.6 \\
\hline Don't & Knov & 18 & 21.7 \\
\hline
\end{tabular}

Total 
While 56 employers claimed that less than 10 percent of their white collar workers retired before ase 65,48 employers claimed that less than 10 percent of their blue collar vorkers retired before age 65. Blue collar workers vere more likely than white collar workers to retire before age 65 in nearly every percentage category. The following crosstabulation suggests that early retirement, before ape 65, is more likely for blue collar vorkers.

TALLE $\quad V-23$

CROSSTABULATIOIN

Early Retirement

by

White Collar and Blue Collar Workers

\begin{tabular}{|c|c|c|c|}
\hline hite Collar workers & $\begin{array}{l}\text { Less than } \\
\underline{10} \frac{\text { Percent }}{56}\end{array}$ & $\begin{array}{l}\text { More than } \\
\text { I0 Percent } \\
3\end{array}$ & $\frac{\text { Total }}{64}$ \\
\hline BI ue Collar workers & 48 & 17 & 65 \\
\hline Total & 104 & 25 & 129 \\
\hline
\end{tabular}

ivote: $x^{2}=3.35 \%$

* Significant at .05

Thus, early retirement before age 65 seems to be more conmon for blue collar workers. Again, this conclusion is consistent vith the employer's cxpectation that white collar workers are more likely to work longer.

In attempting to estimate the likelihood that older workers would be allowed to case radually into retirement through such personnel policies as flextime, part-time options or jot redesign, respondents vere astied to indicate if they 
allowed any of these options.

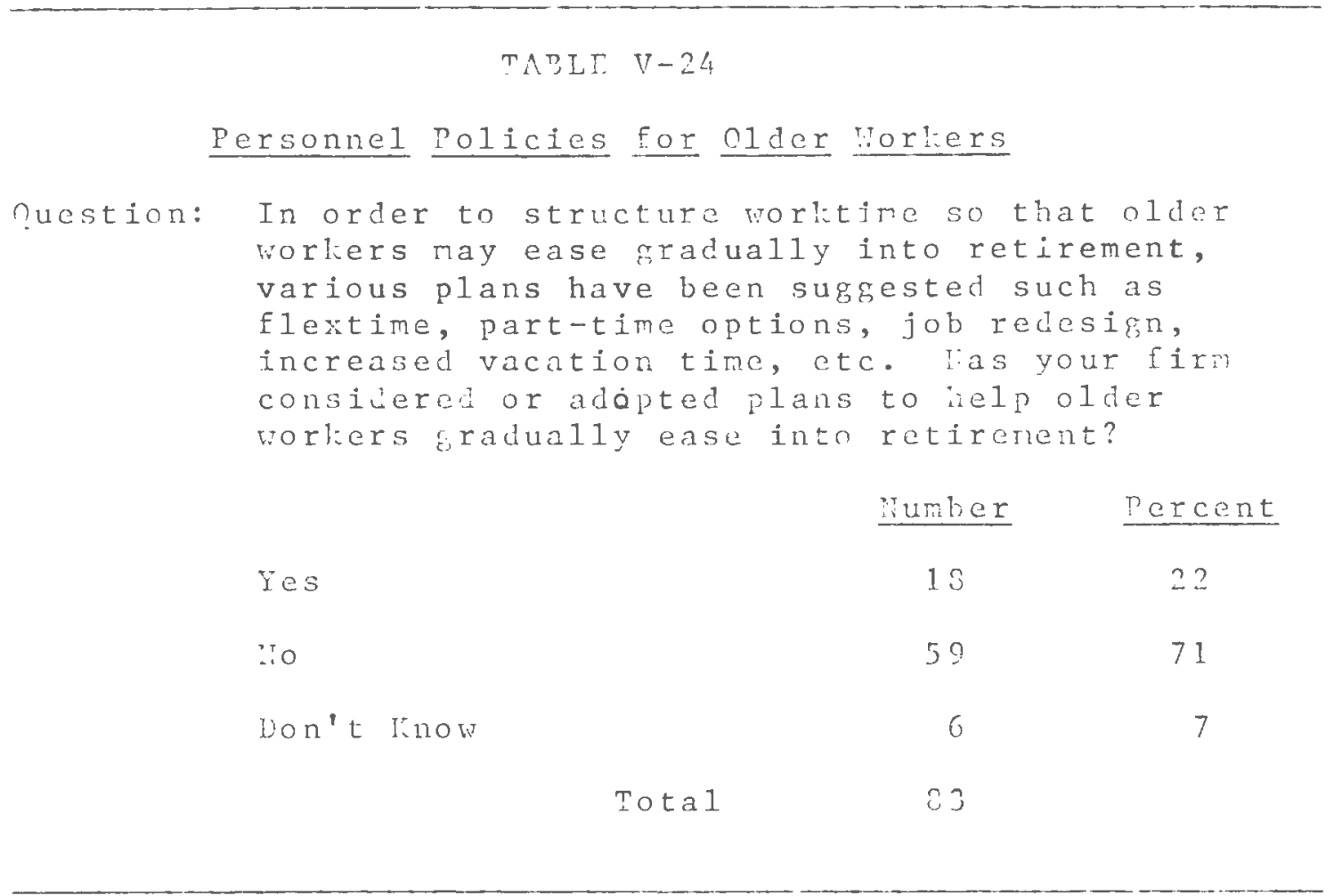

ivarly one quater of those surveyea indicated that they had aciopted personnel policies desioned to assist older worlers in preparing for retirement. The enployers using flexible personnel policies were nearly unanimous in their use of part-time options for worlers. Generally, cmployers indicated that workers could combine reduced hours vith a reduced vork week. One respondent indicated that older workers also could change assignments to a less strenuous one, and another respondent claimed the union representing workers at his firm would not allow part-time options for olier vorkers.

The question of whether employers will allow their workers about to retire the option of remaining, if only on 
a part-tine basis, is considered very important. As previously mentioned, Social security is desirned to provide incentives, arounting to $1 / 4$ of 1 percent for each month betreen the ages of 65 and 72 for which an individual defers retirement, providing in effect for an increase of 3 percent per year Eor each year a worker delays retirement. In addition, the earnings test has been increased to $\$ 5,500$ and will be completely abolished for everyone over 70 years of age. Thus, these two changes are expected to increase the lirelihood that older workers will remain in the workforce, thereby decreasing the job opportunities for younger workers and simultaneously depressing relative vages for younger workers. ivearly one quarter of the employers in the sample already allow vorkers the option of remaining in the workforce in some reduced capacity, increasing the possibility that opportunities for younger workers will be reduced.

When employers were questioned about whether long term historical trends toward early retirement would be changed, they were evenly split in their expectation concerning this trend. The following table displays the responses of employers to the question of early retirement. 
TABLE V-25

Expect Cinanges in ivational Trend Toward Early Retirement

Question: In recent years many men and women have elected to retire before age 65, particularly at age 62 , when reduced Social security benefits first become available. Do you expect any changes in this national trend tovard early retirement?

$\begin{array}{lcc}\text { Yes } & \text { Number } & \text { Percent } \\ \text { No } & 33 & 40 \\ \text { Don't Know } & 34 & 41 \\ & 16 & 19\end{array}$

Total 83

Significant numbers of employers do think that historical chances will in fact be alturec, and that workers vill remain in tire workforce past age 65. At least one employer indicated that ligher living costs would force more older vorlers to remain in the labor force. Then questioned further, employers also believe that both men and women will worl: for longer periods of time.

\section{TABLE V -26}

Expect Different Work Patterns for Yen and Iomen

nuestion: If yes, do you think there rill be any differences in the vork patterns of men as opposed to the worl: patterns of woren?

\section{Number Percent}

\begin{tabular}{|c|c|c|c|c|}
\hline 25, & & $\begin{array}{l}\text { lonerer } \\
\text { women vill }\end{array}$ & 8 & 24 \\
\hline & & rort: Jonner & 1 & 3 \\
\hline 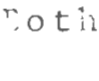 & sexen & $\begin{array}{l}\text { vill ror } \\
\text { longer }\end{array}$ & 25 & 73 \\
\hline
\end{tabular}


Thus, employers that expect historical trends toward early retirement to be changed percelve these changes to work across the board for all employees.

However, employers, while expecting more workers to work longer, are not in favor of having all workers to be required to work longer. When presented with a question on ralsing the age of eligibility for full Social security benefits to age 68, fully 57 percent of all employers opposed ralsing the age of eligibility. While one-third of the sample did agree that the age of elfgibility should be raised, a significant proportion did not agree that the age should be Increased.

TABLE V -27

Increasing the Eligible Age for Social Security Benefits Question: Last year (1980) the U.S. Secretary of Commerce proposed increasing the age at which Social Security benefits are available to age 68 . Would you be:

Number Percent

\begin{abstract}
Strongly in favor Moderately in favor Somewhat in favor Moderately opposed Strongly opposed Don't know
\end{abstract}

12

8

10

13

34

6
15

10

12

16

41

7

Total

The relatively strong opposition to increasing the age of eligibility for Social security benefits is somewhat surprising, as much has been written on the need to redesign 
the social security systcil. Teriaps the oposition to increasins the aje of elisibility is lest understood witin the contert of the employee appraisal systems that most enployers utilize. The following taile shows that over three quarters of all employers do not have a formal employee appraisal rechanist.

\section{TALLE V-23}

\section{Enployee Appraisal Iysten}

Question: llor rould you characterize your employee perfornance system?

\section{Number Dercent}

rormal

Informal

Don't know
15

76

10
12

63

3

33

Tota 1

Thus, it can be concluded that the majority of employers do not have a formal mechanism to evaluate the performance of their employees, a significant finding that inelps to explain why many employers would be opposed to increasing the age of eligibility for social security benefits. It is also somewhat surprising to find that only 15 percent o? the sample had a formal employee appraisal system, since recent legal activit: at : ct tie federal ani state 1 zvero inas enpirasized the need for objective employee appraisal systens to support unbiased personnel practices. If large 
numbers of older vorkers werc suddenly to decide to remain in the workforce, it is conceivable that most employers would be unable, except in an informal contert, to decide who should be allored to work. Thus, it is likely that given changes in the age of Social security eligibility and other areas of retirement policy, older worliers will be more inclined to seek legal remedies in the event they are discharred from their jobs. To some extent this has altegdy occurred, as the Comission for Human Rights has had numerous age discrinination complaints against manufacturing firms.

The majority of employers do not expect to apply their employee performance appraisal practices more rigorously because of the 1978 ADEA Anendments. Tn large measure, this should be expected as fer firms even have a formal process.

TABLE V V-29

Effect on Imployee Appraisal Systems

Question: Do you expect your firm to apply its perfornance appraisal practices more rigorously in the future becausc of the changes in retirement age policy?

vumber Percent

Yes

6 7

No

68

Don't know

Total S.3

In fact, the six respondents clained that their performance aplraisal practices vere to be more riporously applied 
to protect the company from "incompetant" rorhers, to increase productivity and to assure proper records. There was no discernible pattern among employers with respect to applying thoir employee appraisal systems in lirht of the 1978 ADTA Amendments.

Tho aprarent lacl: of a formal employee performance apraisal syster on the part of many firms is also demonstrated in the lacl: of a formal process to provide retrairing for employces. ilany employers, 13 or 16 percent of those sampled, indicate that they provide retraining hy sending: erployecs to conferences, seminars anc conventions wiih a similar number of employers, 14 or 17 percent, indicating that they pay tor educational courses taken by employees. Still other erployers provide for their retraining necds by lifing consultants to provide "in-bouse" training or "y on-the-job trainjng. Irovever, 52 employers or 63 percent, do not provide retraining by ang formal procoss.

The folloving table illustrates the distrilution of respomses to the question of llow employers provice for tive retraining needs of their cmployees. 
TASLT. $V-30$

IIOV Do rou Provide Petraining

?uestion: liov do you provice for the retraining naeds of your employees?

Tunter Percent

Send to conferencos, semirars

or conventions

Pay for educational courses

llire consultants to provide

Other

vortisinops

Conferences, educational

courses and consultants

Conferences, educational

courses, consultants anc

other

Conferences and educational

courses

ivo formal process

Don't Know

$\begin{array}{rr}4 & 4.8 \\ 5 & 6.2 \\ 4 & 4.2 \\ 3 & 3.6 \\ 2 & 2.4 \\ 1 & 1.2 \\ 6 & 7.2 \\ 52 & 62.7 \\ 6 & 7.2\end{array}$

Total

33

Generally, it can be concluded that most firns do not have a formal. procedure either to evaluate an eriployees's job performance or to provide for any additional job training or job retraining.

In addition to the retraining of all workers, employers were ashed if there were any specific occupations or trades in wilch they sought to retrain olcer vorkers. As might bc expected, very few employers specifically geared any training programs specifically for older workers. 


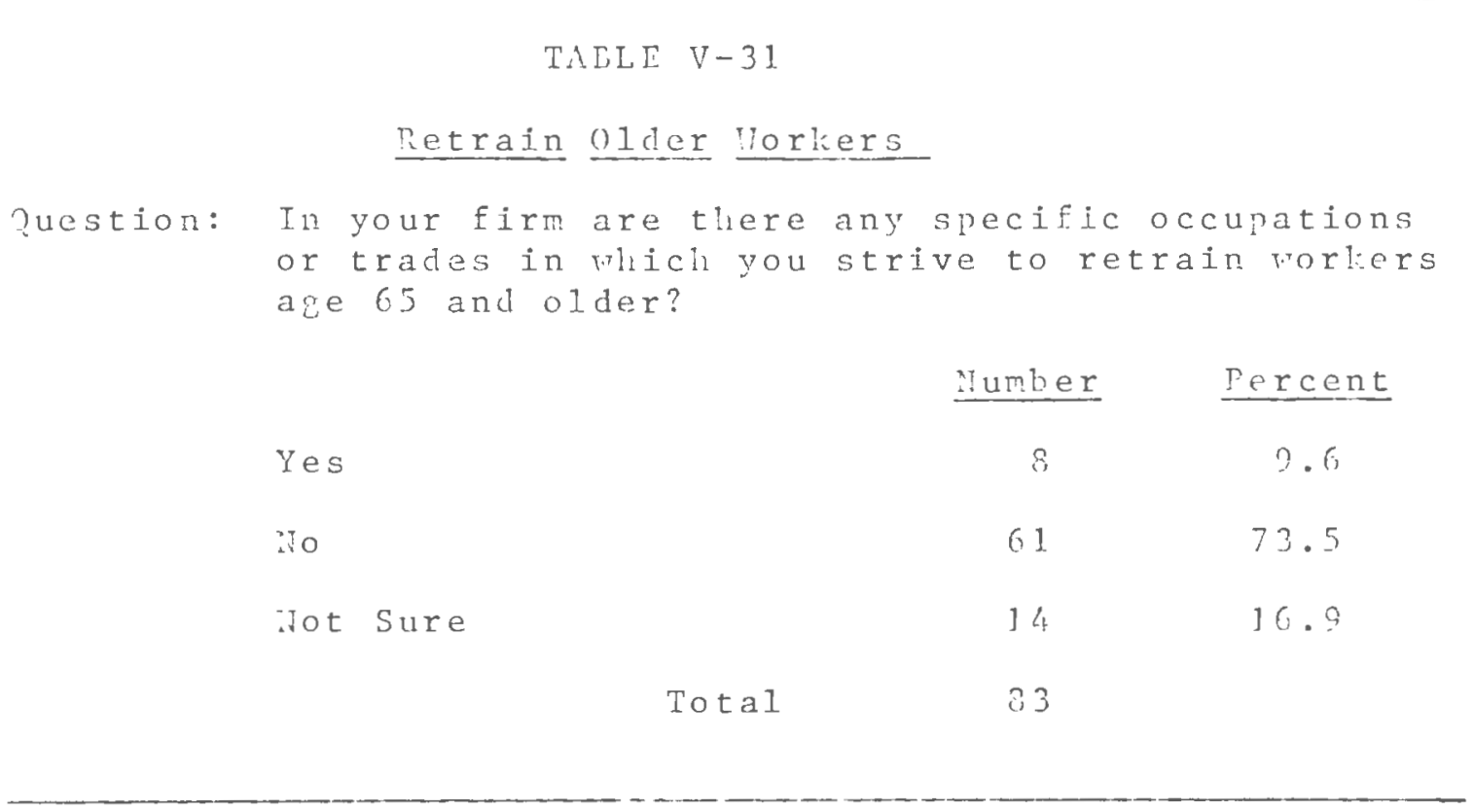

It can be concluded that retraining olcer vorkers will not pose a substantial impediment to job opportunities for youncer workers, as less than one employer in ten seeks to retrain workers age 65 and older.

An identical number of employers also believe that retraining older workers will bloch lines of advancerent for workcrs. The internal competition vas specifically identified by a number of respondents to involve management, technical workers and unskilled workers. However, the majority of employers do not provide retraining specifically for older workers and would therefore not expect any significant decrease in opportunities for other vorlers. 


\section{TABLE $V-32$}

Will Retraining Block Advancement

Question: Do you anticipate that retraining older workers to age 70 will block lines of advancement within any specific occupation or among certain types of workers?

\begin{tabular}{|c|c|c|}
\hline & Number & Percent \\
\hline Yes & 8 & 9.6 \\
\hline No & 41 & 49.4 \\
\hline Don't know & 34 & 41.0 \\
\hline
\end{tabular}

Tota 1

Although large firms of 100 or more employees perceived that retraining older workers would block lines of advancement for other workers with a greater frequency than did other, smaller firms, no significant relationship was found to exist.

However, when employers who expected that retraining older workers would block advancement were compared by SIC code disaggregated into durable and non-durable industries, a significant relationship was found. It appears that firms producing durable goods were likely to view retraining older workers as a threat to the job opportunities of workers. To some extent this relationship might have been expected, as the durable goods industries have been particularly hard hit during the last few years and are likely to view any policy changes that suggest that retirement for workers will be postponed to adversely affect job opportunities for 
workers. The relationship is shown in the following table.

TABLE $\quad V-33$

CROSSTABULATION

Will Retraining Bloak Advancement by SIC Code

$\begin{array}{rrccc} & \text { Yes } & \text { No } & \text { Total } \\ \text { Durable goods } & 7 & 36 & 43 \\ \text { Non-durable goods } & 1 & 39 & 40 \\ \text { Total } & 8 & 75 & 83\end{array}$

Note: $\mathrm{x}^{2}=4.516 \%$

*Significant at .05

Thus, the industry in which a firm is classified seems to be a better predictor of whether retraining will block advancement than does a firm's size.

When employers were asked to Identify the effect the ADEA w111 have on hiring older workers, fully 83 percent of the employers believed they would not change their present policies. Only 6 percent felt they would hire more older workers and less than 4 percent belleved they would hire fower older workers. As the next table 11lustrates, firms expect to continue past hiring practices and do not display any significant movement toward hiring more older workers. 
TABLI V -34

Tolicies Toward IIring Older Iorlers

Question: That effect do you expect the changes in retirement age to iave on your orranization's policics tovara hirins oI: r: 'ars. Till your firin:

i1: $2 x \quad$ Percent

IIire more older workers

Not change hiring policies

ilire fewer older workers

Don't rinot.

$\begin{array}{rr}5 & 6 . ? \\ 69 & 33.1 \\ 3 & 3.6 \\ 6 & 7.2\end{array}$

Total

33

The predeeding discussion indicates that many employers have not experienced any significant impacts from the 1978 ADEA Amendments. In an effort to guage the future implications of the 1978 amendments, employers were asked to evaluate the retirement decision of their workers under the assumption that the high inflation rates of the past few years vould continue. This question is considered a critical question in the survey, as it is assuned that it will predict the future behavior of workers.

To a 1 arge extent, the responses provided in the following table portend a reversal of historical patterns toward early retirement. As discussed in previous chanters, labor force participation rates have been declining, for all workers, with age 65 as the age when many employees retire. However, early retirement before age 65 had been becoming more of the norm for most trorlicrs, and, in fact, the trend was 
toward retirement at an age earlier than 65.

\section{TABLI V -35}

Inflation and the Retirement Decision

?uestion: Continued hirh inflation rates may result in employees choosing to remain in the labor force last carly and/or normal retirement ares. If. inflation continues at the present rate, what affect vould you expect it to have on the retirement decisions of the older worlier in your organization? Tould they:

Eumber Percent

Forego early retirement

Retire at the normal retirement

Wish to continue working past

the normal retirement age

Not change their retirement

plans

Lotir forero rarly retirement and worl: past the normal retircment are

Don't Trow
13

15.7

afe

11

32

11

13.3

5

11

6.7

13.3

Total

83

The sifnificance of tle above information is that 73

percent of all respondents believe that under continued high rates of inflation, workers will not elect carly retirenent. In adition, Table v-25 clearly slowed that 34 crnloyer;, or 41 porcent, iid not erpect that the national tread torard carly ratirement voula ho clanece. Tnflation can then le said to uc ar inportant variable in the retirerent hecision. Siace retirellent for most vorkers is cliaracteriacd by a perioc of dissavings, thä is rorlers ulast ajust their Iirostyle to a reduces incone level, it is also a tire rinen 
the financial resources of a worker begin to le dininished. Again, provious chapters have outlined the powerful influence inflation has on a vorter's retirenent incone, particularly if the retirce inas a pension that is not inderes to changes in tire cost of living. It would be reasonable to assune that under hich rates of inflation which exist for lon periods of time, exactly the situation ve have experienced over the last decade, workers rould re-evaluate their decision to retire and, if possible, postpone that decision for as long as possible.

Not only do the majority of employers believe worliers will not retire at an early age, but a majority of employers also belicve that workers vill retire either at the normal arge or work beyond the normal retirement age.

Attempts to isolate variables that rould influence this decision proved unsuccessful. Crosstabulations dic not produce any siknifjcant relationships. Thus, it is concluded that these trends away from both early and normal retirement exist across tie board for all firrs included in the survey.

When employers vere queried on the impact that the ADEA will have on different groups of employees, there were significant cifferences in the expected impact. Jmployers were asked to rate the affect on job opportunities for youncer workers, women, minorities and older vorkers, using a scale from "æreat effect" to "no effect." The folloring table sumarizes the responses to job opportunities for all four groups. 


\section{TABLE $\quad \mathrm{V}-36$}

Impact on Job Opportunities for Different Groups

Question: Since retirement age policy now prohibits mandatory retirement before age 70 , job opportunities for various groups of your employees may be affected. opportunities for some may be reduced, while opportunities for others may be increased. Using a scale from great effect to no effect, please Indicate the extent to which you expect job opportunities to be effected in your firm. Please use the following codes: 1-Great Effect; 2-Moderate Effect; 3-Some Effect; 4-Little effect; 5-No Effect; 6-Don't know.

Group

Effect

\begin{tabular}{|c|c|c|c|c|c|c|c|c|c|c|c|c|}
\hline & \multicolumn{2}{|c|}{ Great } & & \multicolumn{2}{|c|}{ Some } & \multicolumn{2}{|r|}{$1 \mathrm{e}$} & \multicolumn{2}{|c|}{ None } & \multicolumn{2}{|c|}{$\begin{array}{l}\text { Don't } \\
\text { Know }\end{array}$} \\
\hline & $n$ & $\%$ & $\#$ & $\%$ & $\#$ & $\%$ & $\#$ & $\%$ & \# & $\%$ & $\#$ & $\%$ \\
\hline Younger workers & 5 & 6 & 9 & 11 & 9 & 11 & 21 & 25 & 29 & 35 & 10 & 11 \\
\hline Minorities & & 2 & 5 & 6 & 10 & 12 & 17 & 21 & 38 & 46 & 11 & 13 \\
\hline Women & 2 & 2 & 3 & 4 & 5 & 6 & 23 & 28 & 39 & 47 & 11 & 13 \\
\hline older workers & 6 & 7 & 12 & 15 & 4 & 5 & 15 & 18 & 35 & 42 & 11 & 13 \\
\hline
\end{tabular}

As the table 111 ustrates, younger workers are perceived to be most affected by the changes in retirement age policy. Over one-fourth of all employers belleved that younger workers would, to some extent, have reduced fob opportunities as a result of the ADEA. A similar estimate exists for older workers, as 22 employers or 28 percent, believed that job opportunities for older workers would be reduced to some extent. At this point, it should be stated that the construction of the question may have confused some of the respondents into thinking that the question allowed an answer as to which group experienced an increase in job opportunitiesm which it 
did not. Thus, the responses only for older workers are not considered reliable. Only one in flve employers estimated any impact for minority workers and one in eight employers belleved that women would be affected.

Extensive crosstabulations were conducted to determine if there were any variable sets that would serve as a predictor of differential impacts. These crosstabulations were conducted using the estimated job opportunity impact as the dependent variable. Independent variables were SIC code, average employment, years in business, retirement deciston under high inflation and employee appraisal systems. Crosstabulations were run for all four employee groups with no significant relationships emerging.

The most significant finding of these analyses concerned the lack of any independent variable that served to indicate a relationship between employers and their estimate of how job opportunities will be affected. To the extent that the survey results are representative of the manufacturing community, it can be posited that the impacts will be felt across the board by all manufactuning firms, regardless of SIC code, years in business or other characteristics.

Thus, 1t can be concluded that the ADEA will impact younger workers most significantly. Additionally, minorities and women are not expected to be adversely affected by the ADEA, with women the least expected group to be affected. 
In attenpting to hovelo? the policy inglications of this analysis, a number of important observations can bo lade. Tirst, mandatory retirement policies vere not as widespread as might be expected. Only 16 percent of the sample reported a mandatory retirement policy in 1277, riti a sinificant relationslip found to exist betreen the

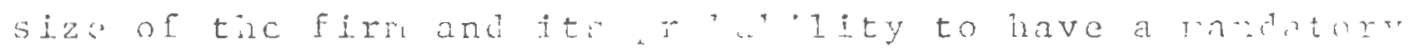
Istirement policy. As noted previously, Rhode Island has a greater proportion than the national average of nanufacturing. firms employing, fever than 100 workers, which undoubtedly contributes to the lor proportion of workers covered by a mandatory retirenent policy. The importance of the lack of a mandatory retirement nolicy has resulted in the fact that many employers have had previous expericnce vith workers remaining on the job past aro 65 . Thile large numbers of workers not subject to a retirement policy retired at age 65 anywa, 50 employers, or 6n percent of. the sample, claimed to have had some employecs vorl past afe 65.

Generally, employers expecter that white collar vorkers would most likely remain in the workforce, with executives, 
clerical, technical and management staff considered the most probable groups to continue working. However, employers without a mandatory retirement policy fully expect some blue collar workers to want to work longer, a conclusion that should not be overlooked as these employers have had blue collar workers remain past age 65 and should be better able to estimate which workers are likely to continue working. In addition, the survey results also suggested that blue collar workers have historically retired at an earlier age than the age of retirement for white collar workers, suggesting that early retirement is most $11 k e 1 y$ a preferred option for blue collar workers.

When employers were questioned on their views of "uncapping" mandatory retirement, the majority of employers agreed that mandatory retirement should be abolished and predicted that it would have little or no affect. Firms which have had mandatory retirement policles in the past appeared most apprehensive about uncapping the age of retirement.

Employers were evenly divided on the question of whether they expect the trend toward early retirement to change, and those that did expect a change believe that both men and women w11l want to work longer. Surprisingly, most employers do not agree with proposed changes to increase the age of eligibility for Soclal Security benefits, as fully 57 percent of all employers registered moderate to strong opposition to this question. 
Significantly, 50 employers or 60 percent of the sample, speculated that under continuing high rates of inflation workers would either forego early retirement or continue working past the normal retirement age. This is considered to portend the reversal of the historical pattern toward early retirement, and may play an important role in determining the long-term implications of the ADEA. From the Information gathered during the survey, there has not been a dramatic short-term shift in the retirement practices of many workers. However, the perceived threat of continuing high inflation clearly stands out as a major variable in the future retirement decisions of workers currently in the labor force. Thus, the long-term implications of the ADEA may well be determined by how well the country is able to control inflation.

Another important finding relates to the area of personnel policies affecting workers. Nearly 25 percent of all employers provide older workers with flexible arrangements in order to allow these workers to remain on the job. To the extent that future retirement policy changes alter the incentives for older workers to remain in the labor force, such as through raising or eliminating the earnings test, increasing the age of eligibility for social security benefits or increasing through additional incentives the possibility that older workers continue working, we will probably see more workers work for longer perlods of time. This conclusion, although made more from inferences in the 
survey than from any specific questions contained in the survey, rarrants closer attention to tine issue of further changes in retirement policy.

Perlaps tile nost iriportant fincing in tlee area of personinel policies is that over tiree-fourtas of ajl employers dio not have a fornal enployee performance appraisal. system. This is considered very important for a number of reasons. First, emloyees ray imitiate an are discrimination case With a private attorney as well as seek remedies through the IIOC, and to the extent that the private har is willing to take these cases, we are likely to see more litioation nver age discrimiration. Second, in deternining the merits of an age discrimination case, courts will closely eyarine the performance appraisal systems utilized by employers, and strike down those that are not comprehensive and clo not apply to all worlers. Thus, assuming the scenario of continued inflation and informal employee appraisal systems, we are likely to witness an increase in the number of are discrimination cases against manufacturing firms in phode Island. Consistent with this finding is the fact that 63 percent of all firms surveyed have no formal process to provide retraining for their crployecs, althoush over 30 percent of the firms provide retraining throurh such practices as sending workers to conferences, seminars, conventions, yiring consultants to do "in-house" training and by paying for

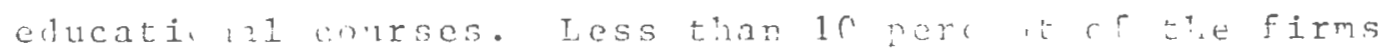
survara strive to retrain oldor rorlors ard a sinilar 
number believe this retraining for older workers will block Iines of advancement for younger workers. This finding was particularly true for firms manufacturing durable goods.

In terms of the 1mpacts on various groups of workers, the survey results clearly show that younger workers are most 1ikely to be affected by the changes brought about by the ADEA of 1978. For younger workers, the impacts w111 $11 k e l y$ be a decrease In job opportunitles, as well as a decrease in relative wages resulting from an inability to be promoted Into better paying positions. The decreases will likely affect many younger workers regardless of the skilled or unskilled nature of their job.

While the information on the perceived impacts for younger workers is falrly stralghtforward, the impacts for older workers must be qualified. As a result of the wording of the question, it appears that there may have been some confusion on its interpretation. The wording of the question may have confused some respondents into assuming that the question allowed a response to indicate that job opportunities were being increased for some workers, when the intent was to Identify which groups lost job opportunities. Thus, the information provided in the responses under older workers must be considered Invalid. This caveat is applicable only to the older workers category.

It appears that the policy impact from the ADE $\Lambda 111$ be greatest for younger workers. They w1ll face increasing difficulty in obtaining manufacturing employment and in 
advancing internally once in the position. To the extent that white collar workers remain on the job longer than blue collar workers, competition for white collar jobs will be most pronounced. Additional changes in retirement age policies, particularly those that provide incentives for older workers to remain in the workforce, are $11 k e 1 y$ to be successful and will encourage more people, both men and women, to work for longer perlods of time. Continued high inflation is anticipated to be a powerful stimulus for workers to remain on the job and when combined with the policy changes currently being discussed on the Federal level, may decrease dramatically from the overall job opportunities and advancement possibilities for younger workers.

In addition, the following suggestions are offerred for consideration. First, manufacturing firms should review their personnel policies to assure that these policies will be in concert with the legislative changes, as well as with the potential changes suggested by the survey results. One obvious area of concern is the process used to evaluate the performance of workers. Recent court cases Involving age discrimination have indicated that employers must utilize a reasonable performance appraisal system that is job related, written, objective and free of age bias. In as much as the majority of employers characterized their personnel appraisal systems as informal, it is likely that these systems would not withstand legal scrutiny. 


$$
\therefore \text { so companies should soe', as muc': as possible, to }
$$

have a broad and oquitable age distibution across cornany shill lines. This conclusion is predicated on the fact that a nuiber of firris in the survey indicated they specifically sought to retrain older worler: in certain specialized crapts, suggesting t?at if a curnany has too many older workers in certain areas it ith vounter future stits rendaceracat problens.

In yet another vein, the survey results suggest that competition for white collar positions will be most pronounced. Even without the changes brought about by the ADEA, competition for these middle-managenent and professional positions was expected to be intense. The ADEA will further exacerbate this situation. Thus, it is lirely that many professional and managerial workers will cxperience mid-career crises at earlier ages. The result is likely to be greater instability, turnover, and, most damaging to the economic vitalit: of the state, outmigration from Rhode Island to other parts of the country. This implication is particularly problenatic, althougli carcer counseling and job retraining arc possible approaclues to mitigating this problem rithin individual firas. Since nearly 63 percent of all firms do not have a formal process for providing retraining for their erployces, businesses should reach out to educational institutions to provide tinis retraining. Lducational institutions have an inperfect grasp of the retraining needs of many firms and Eusincsses should he more villing to articulate their 
retraining needs. Iowever, the most olvious, alleit most difficult, solution is to create an environment which malies the state an attractive place for companies to expand or relocate their businesses.

Finaly, given the large numbers of older vorkers in the state, it is clcar that the retirement ciecisions of workers are an inportant component of the economic healt? of the state. State agencies should tramine future developrents through appropriate social indicators in orier to keep abreast of potential changes in retirement patterns, as well as by closcly monitoring all lerislative thrusts that may affect the retirement decisina of ron tiers. 


\section{FOOTNOTES}

I"Summary of Legislation," Congressional Quarter1y Almanac, 95th Congress, 2nd Session...1978, Volume XXXIV (December 1978), p. 12.

${ }^{2}$ U.S., Department of Labor, Employment and Training Report of the Pres1dent, 1979 (Washington, D.C.: Government Printing Office, 1979), p. 279.

${ }^{3}$ U.S., Congress, Senate, Subcomittee on Labor, Age Discrimination in Employment Amendments of 1977 on S. 1784 . 95th Congress, 1st Session, 1977, p. 77.

${ }^{4}$ Charles N. Weaver, "Workers' Expectations About Losing Their Jobs," Monthly Labor Review, (Apr11 1980), p. 53.

${ }^{5}$ U.S., Congress, Senate, The Next Steps In Combating Age Discrimination In Employment: With SpeciaI Reference to Mandatory Retirement Policy, A Working Paper, by Marc Rosenblum, Special Committee on Aging (Washington, D.C.: Government Printing office, 1977), p. 6 .

6U.S., Department of Labor, Employment and Training Report of the President, 1978 (Washington, D.C.: Government Printing Office, 1978), p. 95.

7 Barbara L. Schle1, Employment Discrimination Law, (Washington, D.C.: The Bureau of Nat Ional Affa1rs, 1979), p. 109 .

${ }^{8}$ Steven Seeberg, "Cholces Avallable in Amending PIans to Meet the New Age 70 Retirement Rules," Journal of Taxation, (August 1978), p.67.

${ }^{9}$ U.S., Department of Labor, Age Discrimination in Employment Act of 1967, A Report Covering Activities Under the Act During 1977 (Washington, D.C.: Government Printing Office, 1977), p. 11.

10 U.S., Department of Labor, Age Discrimination in Employment Act of 1967, A Report Covering Activities Under the Act During 1978 (Washington, D.C.: Government Printing off 1 ce, 1978), p. 9 .

$11_{\text {Rhode Island, Commission for Human Rights, Annual }}$ Report 1979, p. 2. (Typewritten.)

12 Donald E. Sullivan, "Never Too 01d," The Personnel Admin1strator, (June 1978), p. 56. 
${ }^{13}$ Ph1l1p L. Rones, "O1der Men-the Cholce Between Work and Retirement," Month1y Labor Review, (November 1978) p. 3.

14 Janice Halpern, "Raising the Mandatory Retirement Age: Its Effect on the Employment of O1der Workers," New England Economic Review, (May-June), p. 24 .

${ }^{15}$ U.S., Congress, House, Mandatory Retirement: The Social and Human Cost of Enforced Idleness, Committee Pub1ication 95-91, 95th Congress, Ist Session, 1977, p.1.

${ }^{16}$ Sar A. Levitan, Garth L. Mangum, and Ray Marshall, Human Resources and Labor Markets (New York: Harper and Row, 1972), p. 321 . p. 1 .

${ }^{17}$ Idem, The Socta1 and Human Cost of Enforced Idleness,

18 Work in America Institute, The Future of older Workers In Amer1ca (New York: Scarsdale, 1980), p. 39 .

${ }^{19}$ Ibid., p. 40 .

${ }^{20}$ Idem, "0lder Men-the Choice Between Work and Retirement," Monthly Labor Rev1ew, (November 1978), p. 5.

21 U.S., Congress, House, Public Policy and the Future of Work and Retirement, Committee Publication 95-143, 95th Congress, 2 nd Session, 1978, p. 57.

22 Idem, Employment and Training Report of the President, 1978, p. 31 .

${ }^{23}$ Ibid., p. 97.

24 U.S., Congress, House, Active Americans Over 65 Speak on Ret1rement Age Policies, Committee Publication 95-92, 95 th Congress, 1st Session, 1977, p. 1 .

25 Idem, Public Pollcy and the Future of Work and Retirement, p. 21 .

26 Ibid.

27 Louls Harris and Associates, Inc., The Myth of Aging In America, (Washington, D.C.: National Council on the AgIng, 1975) p. 212.

28 Idem, Senate, Age Discrimination in Employment Amend-

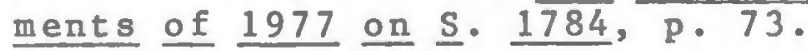


${ }^{29}$ Idem, "Raising the Mandatory Retirement Age: Its Effects on the Employment of Older Workers," p. 31.

${ }^{30}$ Idem, Senate, Age Discrimination In Employment Amendments of 1977 on $\underline{S}$. $1784, p \cdot 344$.

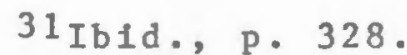

32 Ibid., p. 331 .

${ }^{33}$ Lois F. Copperman, Douglas G. Montgomery, Fred D. Keast, The Impact of the ADEA Amendments of 1978 on the Private Business Community (Portland, Oregon: Portiand State University School of Urban Affairs, 1979), p. 28.

34 Ib Id., p. 29.

35 Ib1d., p. 159 .

36 Ibid., p. 188 .

37The Bureau of National Affairs, "ASPA-BNA Survey No. 39 Retirement Policies and Programs," (Washington, D.C.: The Bureau of National Affairs, Inc., 1980), p. 10. ${ }^{38}$ Ibid.

${ }^{39}$ Ibid. 
APPTMINA

SURVEY INSERUETTS 
Next week a questionaire:from the Rhode Island Statewide Planning Program will be mailed to your firm. Our survey is the first statewide study of the opinions of the Rhode Island ousiness community on the impacts of raising the retirement age from age 65 to age 70. Your company was randomly selected from a list of Rhode Island businesses and your cooperation in providing us with this information is crucial if we are to accurately understand the effects of the changes in retirement age policy.

Thank you in advance for your cooperation 


\section{AGE AND EMPLOYMENT PRACTICES SURVEY}

For classification purposes, please provide the following information:

Q1: How would you characterize your firm's business activity usinn a two-diqit code from the Standard Industrial Classification code?

Q2: Which category most accurately reflects your averane employment?

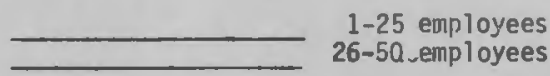

Q3: Approximately how many years has your firm been in business in Phode Island?

\begin{tabular}{ll} 
less than 5 years & \\
\hline & $6-10$ years \\
$11-25$ & years
\end{tabular}$\longrightarrow$ more than 50 years

We would like to begin with some questions regarding your firm's past policies on mandatory retirement:

Q4: In 1977, did your firm have a mandatory retirement ace for any of its employees?

$$
\begin{aligned}
& \text { Yes (1) } \\
& \text { No (2) } \\
& \text { (ANSWER 05-n12) } \\
& \text { (SKIP TO } n 13 \text { ) }
\end{aligned}
$$

Q5: At what age were white ${ }^{1}$ collar workers mandatorily retired? Age

Q6: Was this mandatory retirement age part of a:

pension or profit sharing plan
company policy
collectively bargained union contract (3)
other (Specify):
Don't Know/No Response

Q7: At what age were blue ${ }^{2}$ collar workers mandatorily retired? Age

Q8: Was this manatory retirement age part of a :

pension or profit sharing plan
company policy
collective?y hamatred union contract
other (Specify):
Don't Know/No Response

Q9: How have you modified, or how do you intend to modify the mandatorv ane in order to comply with the changes in retirement age policy? Have you or will you:

increase to age 70
increase to past age 70
abolish it entirely
leave the age unchanged
Don't Know/No Response

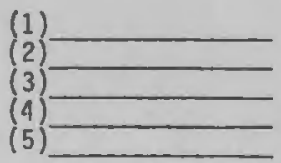
Q10: In the next few years do you expect any of your employees to choose to work past the aoe
of 65 ?

$$
\begin{array}{r}
\text { Yes (1) } \\
\text { No (2) } \\
\text { Not Sure (3) }
\end{array}
$$

Q11: Do you expect any particular group of your employees to work longer than other oroups?

Yes (1)
No
Not Sure (3) $\left(\begin{array}{l}\text { (SKIS TOR Q12) } \\ \text { SKIP TO Q17) }\end{array}\right.$

1White collar workers: professional and technical, managers and administrators, sales workers ${ }^{2}$ Blue collar workers: and clerical workers craft workers, operatives, laborers and service workers 
In order to structure worktime so that older workers may ease gradually into retirement, various plans have been suggested such as flextime, part-time options, job redesign, increased vacation time, etc. Has your firm considered or adopted plans to help older workers gradually ease into retirement?

\section{Yes (DESCRIBE BELOW) \\ NO (SKIP TO Q22)}

Don't Know/No Response

If yes, describe:

(1)

(2)

(3)

Q22: In recent years many men and women have elected to retire before age 65. particularly at age 62 , when reduced Social security benefits first become available. Do you expect any change in this national trend toward early retirement?

$\begin{array}{ll}\text { Yes (ANSWER Q23) } & \text { (1) } \\ \text { No (SKIP Q23) } & \text { (2) } \\ \text { Don't Know/No Response } & \text { (3) }\end{array}$

No (SKIP Q23)

Don't know/No Response

Q23: If yes, do you think that there will be any differences in the work patterns of men as opposed to the work patterns of women?
Yes, more men will work longer
Yes, more women will work longer
(1)
Both sexes will elect to work longer
(3)

Q24: Last year (1980) the U. S. Secretary of Commerce proposed increasing the age at which full Social security benefits are available to age 68 .

would you be:

$$
\begin{aligned}
& \text { strongly in favor } \\
& \text { moderately in favor } \\
& \text { somewhat in favor } \\
& \text { moderately opposed } \\
& \text { strongly opposed } \\
& \text { Don't Know/No Response }
\end{aligned}
$$

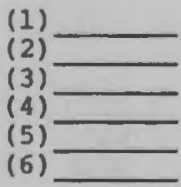

Q25: In your firm are there specific occupations or trades in whbch you strive to retrain workers age 65 and older?
Yes
No
(1)
mn't rnow/run Reanonae
(3)

Q26: How do you provide for the retraining needs of your employees?

\begin{tabular}{ll} 
send to conferences, seminars, conventions & $(1)$ \\
pay for educational courses & $(2)$ \\
hire consultants to provide "in-house" workshops & (3) \\
other (Specify): & (4) \\
\hline don't provide retraining by any formal process & (5)
\end{tabular}

Q27: Do you anticipate that retraining older workers to age 70 will block lines of advancement within any specific occupation or amonq certain types of workers?
Yes (Specify):
(1)
Don't Know/No Response
(3)

Q28: How would you characterize your employee performance appraisal system?

Formal
Informal
Don't Know/No Response

(1)

(2)

Q29: Do you expect your firm to apply its performance appraisal practices more rigorously in the future because of the changes in retirement age policy?

Yes (Why?)
No 't Know/No Response

(3)

Q30: What effect do you expect the changes in retirement age to have on your organization's policies toward hiring older workers? Will your firm:

Hire more older workers
Not change hiring policies
Hire fewer older workers
Don't Know/No Response
(1)

(2)

(3)

(4) 


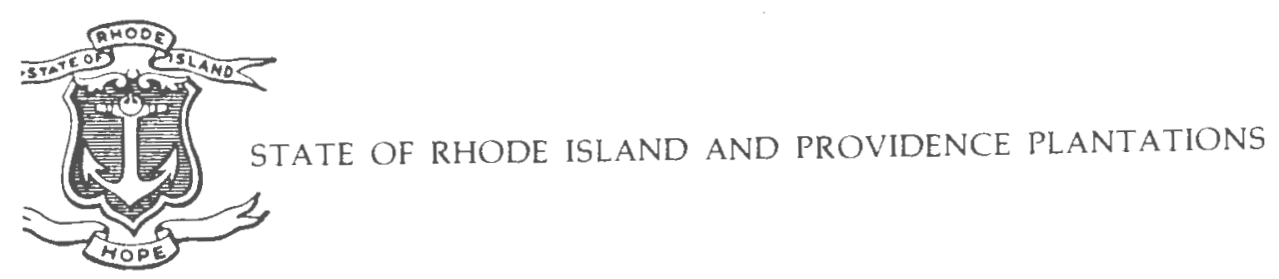

Department of Administration STATEWIDE PLANNING PROGRAM 265 Melrose Street

Providence, Rhode Island 02907

$$
\text { Eebruary } 27,1981
$$

Dear Riode IEland Businessman:

The enclosed survey is tro first statewide study of the opinions of the khod island tusiness commuity on the impacts of raisire the retirement aye from 65 to 70 . Your company was randomly selected from a list of phode Isiand businesses and your cooperation in providing us with irfornation is crucial if ve are to accurately understand and onan for the effects of this charge in retirement age policy.

please be assured that all responses will be held in the strictust confidence and results rill be displayed only in the aggregate. Snould you reed the results of the survey for planning purposes within your crgarization, or wish to discuss the questicis contaired in the survey, feel Eyet to contact either Eatrick ringliss or John O'Erien of our staff at $277-2656$.

Thank you in advance for your coopsation.

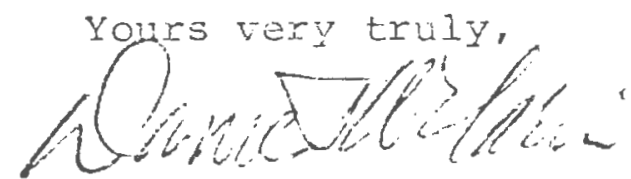

Daniel Varin

Chief

Drv/bam

Enclosure 
STATE OF RHODE ISLAND AND PROVIDENCE PLANTA'TIONS

Department of Administration

STATEWIDE PLANNING PROGRAM

265 Melrose Street

Providence, Rhode Island 02907

March 18, 1981

DEAR. ERTLOY.ER :

Last week, the Rhode Island Statewide Planning Program selected your firm through a random sampling process to participate in a statewide study of retirement age policies. As of today, we have not yet recelved your completed questionnaire.

This statewide study was undertaken in the belief that the opinions of the business communtty should be known and taken into account when determining appropriate federal or state policy. We also believe that information ou hos other organizations are adapting their policies as a result of chatiging socio-economic conditions will be useful to wembers of the business commity.

He are witing to you again because of the significance each questionnaire has to the overall utility of the study. Simply stated, in order for the results of this study to be truly representative of the private business community, it is essential that each firm in the sample return the questionnaire.

In the event that your questionnaire has been misplacce. a replacement is enclosed.

Tour cooperation is greatly appreciated.

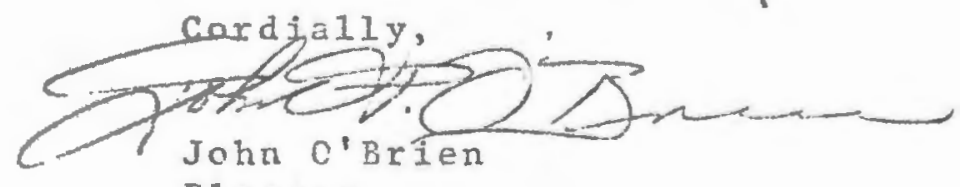

F1anner 


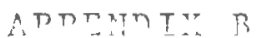

SUMVEY *TTYODOLกחי 
In orier to determine the specific inpacts of the 1073 ADza Amendments for Miroce Island, a rail survey was conciucted of 107 manufacturing firms located in the state. Tine survey sampling plan chosen vas a random stratified sanpling nethodology using tie quota nethod. "anufacturing businesses engaged in the production of goods from standara Industrial C1assification (SIC) coles 20 to 3?, excluding SIC 21 and 29, were surveycd. These tro SIC categories were onitted as there are relatively few Rhode Island firms engaged in tise manufacture of tobacco products (SIC 21) or petrolcum and coal products (SIC 29).

'lanufacturing firms in Phode Isiand vere selccted for the survey sampling plan for a variety of roasons. First, the state Comission for muman zirhts found that almost half of all age discrinination ciares were filed on behalf of individuals employed in manufacturing industries. Second, firms involved in manufacturing employ over 133 , non people in winde Island, or approxinately one-third of the state's total labor force and, as such, play a vital role in the overall economic hoalth of the state. Third, the 1?7? Portland State University study, the most comprehensive analysis of the subject of tive 1078 Airs Amendments, unintentionally uniersampled manufacturins industries, 
attaining, 320 percent response rate from nanufacturing firms while the national distribution of manufacturing industries is over 3? percent. Tourt?, and perings most important, was the existence of the 1979-?n edition of the Directory of "zanufacturers pulilished by the rhode Islanc' Jepartment of Tconomic Development, wich proviced the name, location and number of employees for over 2, 600 manufacturing firms currently located in Rhode Island. This directory provided the framerorl for the randon selection of manufacturing firms by two-digit SIC code and alloved firms with fever than four employees, and not covered under the R.I. State FEPA age discrinination law or the 1978 ADEA Amendments, to be excluded from the sample. The Directory was considered a significant universe record and not a statistical sample, thus enabling it to te used for the purpose of selecting a sample of firms to be surveyed. The following table compares the information containca in the Directory with data available from "rount? gus ios Patterns - 107?" a $7^{3}$ Fourth quarter totais for $197^{n}$ for firms coverci uncer the D.I. Pepartment of Timployment Security (DES). 
TABLE B-1

Comparability of the Directory

with

Selected Data Sources

Number of Firms by SIC Code

SIC Code Directöry ${ }^{1}$ County Business Patterns ${ }^{2}$ DES $^{3}$

$\begin{array}{rrrr}20 & 110 & 132 & 147 \\ 22 & 189 & 192 & 219 \\ 23 & 49 & 60 & 76 \\ 24 & 31 & 49 & 51 \\ 25 & 40 & 31 & 51 \\ 26 & 68 & 56 & 62 \\ 27 & 186 & 191 & 204 \\ 28 & 87 & 67 & 85 \\ 30 & 106 & 95 & 113 \\ 31 & 26 & 24 & 28 \\ 32 & 50 & 43 & 58 \\ 33 & 104 & 103 & 108 \\ 34 & 364 & 390 & 408 \\ 35 & 281 & 292 & 280 \\ 36 & 70 & 64 & 70 \\ 37 & 50 & 44 & 48 \\ 38 & 64 & 45 & 66 \\ 39 & 897 & 929 & 1300\end{array}$

$1_{\text {Totals determined by manual tabulations (1979-80 }}$ Directory of Manufactarers, R.I. Department of Economic Develqpment, 1980).

Totals provided In "County Business Patterns-1977" (U.S. Department of Commerce, pps. 3-6, 1979).

3 Totals provided in "State Summary-Employment and Total Payro11s" R.I. Department of Employment Security, 1978.

As Table B-1 111 ustrates, the Directory is a closer estimate than is the R.I. Department of Employment Security information when compared to the information provided in "County Business Patterns" In all but six (6) instances. 
While it is recognized that all three data sources were prepared in different ways and for different years, the Directory does not reflect any totals that are unrepresentative and do not jeopardize the use of the Directory as a basis for conducting the survey.

As an additional check on the reliability of the Directory as an appropriate sampling resource, the employment totals provided in the Directory were compared to the employment totals provided in "County Business Patterns" and the fourth quarter Department of Employment Security information for 1978. This comparison, presented in the following table, again suggest the Directory is a reliable survey tool as manufacturing employment rose from the 1977 figure provided by the "County Business Pattern" summary of 125,725 manufacturing workers to a 1978 total of 135,745 , as reported by the Department of Employment Security, accounting in part for the discrepancy among some of the totals. In addition, larger totals in the Directory column are a result of the fact that firms producing products that fall into two or more SIC groups are listed each time, with the result that the employment totals are inflated. Similarly, employment totals provided in the Directory appear, in many instances, to be rounded numbers, also inflating the total employment figure for each SIC category. 


\section{Thin: D, - \\ Comparailit. of t'ic Directory \\ vit? \\ Selected Data Sources}

Total Inployment by cic coue

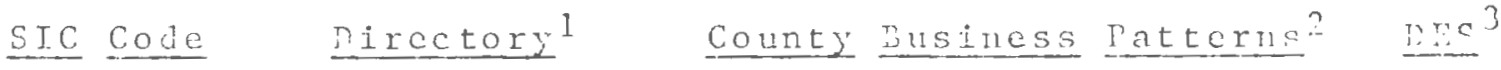

\begin{tabular}{|c|c|c|c|}
\hline 20 & 3,546 & 3,715 & 3,361 \\
\hline 22 & 14,392 & 13,631 & 12,501 \\
\hline 23 & 4,431 & 2,753 & $3,76 \%$ \\
\hline 24 & 468 & $250-499$ & 605 \\
\hline 25 & 1,139 & 338 & 1,101 \\
\hline 20 & 3,713 & 2,717 & 3,12 \\
\hline 27 & 5,058 & $\therefore, 765$ & $5,1,34$ \\
\hline 28 & 0,072 & $?, 036$ & $2, ?$ \\
\hline 30 & 10,121 & $5,27 \%$ & 7,125 \\
\hline 31 & 3,742 & 2,703 & 3,623 \\
\hline 32 & 3,525 & $1,71 !$ & 3,370 \\
\hline 33 & 10,155 & 9.1 & $6,1,79$ \\
\hline 34 & 12,141 & 15,432 & 12,65 \\
\hline 35 & 11,715 & $\therefore 375$ & 2,59 \\
\hline 36 & 10,854 & $n, 5 ? .1$ & 11,78 \\
\hline 37 & 6,660 & $1,0,35$ & 0,13 \\
\hline 35 & 3,468 & 4,900 & 5,342 \\
\hline 32 & 37,839 & $32,1 \subseteq 0$ & $3 n, 1 n$ \\
\hline
\end{tabular}

${ }^{1}$ Totals detcrmined by manual tabulations $(1970-3)$

Directory of Hanufacters, R.I. Jenartment of Fconomic Development, $19 \overline{30}$ ).

2 Totals provided in "County Busincss Patterns-1977, U.S. Department of Commerce, pps. 3-6, 1979.

3 Totals provided in "State Summary-Tmnloyment and Total Payrol1s" T.I. Department of Fmployment Security, 1979.

Thus, the nircctory of lanufacters was determined to provide an acceptable 1ist of the nanufacturing industries located in Rooc Island because the information contained in the Directory was consistent rith other informatinn fror

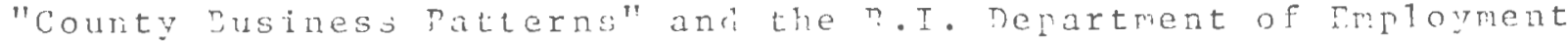


Security. In addition, the Directory was also considered an acceptable universe record because it included firms from all parts of the state and as such can be considered geographically representative of the distribution of manufacturing firms in the state. Finally, the Directory was used because it did not, by design, systematically exclude any firms from being 1isted.

Once the decision was made to use the Directory as the basis for the selection of firms, a sampling plan was prepared. A lottery-type selection of firms was considered, but refected on the basis that it would not guarantee that all sic groups would be included in the survey. In order to achieve coverage in every SIC category from 20 to 39 , excluding SIC 21 and 29 , a stratified sample was considered to be most appropriate. In addition, this stratified sample was constructed to utilize the quota method, rather than the proportional method.

Although the proportional method was considered, it was not used because of Rhode Island's relatively undiverse economic base. A proportional sample would have involved sampling industries by SIC in proportion to the distribution of these firms within the total R.I. manufacturing base. For example, if a proportional stratified survey had been used, SIC 20 (Food and Kindred Porducts) employing about 3 percent of the manufacturing labor force would have resulted in 3 percent of the survey total being selected from this SIC group. This method raised the possibility that if the small number of firms to be surveyed in SIC 20 chose not to 
respond, there would not be any coverage in that SIC group. While the possibility that firms will elect not to respond to a survey is clearly inherent in every survey design, there are survey sampling plans which can, to a large extent, Increase the possibility of coverage in every subset.

In order to achleve the goal of coverage in every SIC category, the sampling plan was designed to include a stratification system using the quota method. The sampling plan was stratified by SIC code, dividing each sIC stratum into three subsets: first, those firms employing between 4 and 19 workers; second, firms employing between 20 and 99 workers; and third, firms employing more than 100 workers. The quota method Involved randomly selecting two firms from each of these subsets, thereby allowing for a maximum of six (6) firms from each SIC code. Thus, the sampling plan allowed for a maximum of 108 surveys, a result of six (6) surveys for each of the elghteen (18) sIc codes. Once the random sampling began 1t became apparent that SIC 24 (Lumber and Wood Products) would not legitimately provide the required number of responses. As a result, this sIC was sampled to include only five (5) firms, Instead of the goal of six (6) firms, reducing the total number of surveys to 107.

The following table shows the distribution contained in the Directory of firms by size and highlights the sampling constraint in SIC 24. 


\section{TAELL $5-3$}

SIC Code iy Inployment Size

\begin{tabular}{|c|c|c|c|c|}
\hline SIC Cocie & $1-1 ?$ & $20-99$ & 100 or more & $\begin{array}{l}\text { To } \\
\text { Response }\end{array}$ \\
\hline 20 & 65 & 30 & 8 & 6 \\
\hline 22 & 49 & 22 & 48 & 10 \\
\hline 23 & 25 & 12 & 12 & 0 \\
\hline 24 & 22 & 6 & 1 & $\Omega$ \\
\hline 25 & 20 & 8 & $?$ & 2 \\
\hline 26 & 17 & 35 & 13 & 3 \\
\hline 2.7 & 110 & 41 & 14 & 13 \\
\hline 28 & 49 & 27 & 12 & 5 \\
\hline 30 & 39 & 42 & 22 & 3 \\
\hline 31 & $\theta$ & 12 & 5 & 1 \\
\hline 32 & 23 & 16 & 7 & $l_{t}$ \\
\hline 33 & 48 & 29 & 22 & 5 \\
\hline 34 & 200 & 115 & 25 & $2 t$ \\
\hline 35 & 186 & 70 & 10 & 7 \\
\hline 36 & 16 & $2 \delta$ & 24 & 11 \\
\hline 37 & 25 & 13 & $?$ & ' \\
\hline 30 & 27 & 20 & 13 & 4 \\
\hline 32 & 424 & 303 & 36 & 79 \\
\hline
\end{tabular}

Source: Manual tabulations of the Directory of lanufacturers, R.I. Departnent of Fconomic Development, 1970-in.

The information in the prececing table is particularly useful in identifying a number of specific concerns regarding the survey metiodology. In all but five sIc caterories, small firms employing less than tventy workers constitute over half of the total number of manufacturing firms cloing. busincss in the statc. This large number of small firns is somevhat higher than the national distribution of srall firms, althoun nationally snall firms comprise over one quarter of all businesses. Ilowever, the sampling plan vas constructor

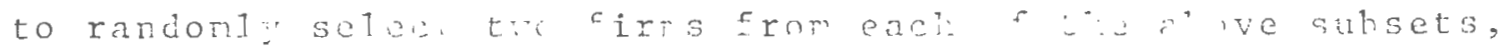
caere: ro rucing the number of amall firms, as a pronortion 
of the total, and increasing the number of medium and large firms, again as a proportion of the total. The sampling plan can then be criticized on the basis that it undersampled small firms by utilizing the quota method rather than the proportional method. However, it should be pointed out that the Portland State study found the greatest impacts of the 1978 ADEA Amendments among large firms and the sampling plan was constructed under the assumption that the size of the firm was an Important variable in assessing the impacts of the legislation.

A second concern of the sampling plan regards the arbitrary selection of the total number of firms included in the sample. As a result, the sampling plan can be criticized on the basis that it undersampled certain SIC categories by utilizing the quota method. For example, SIC 20, which employs about 3 percent of the total manufacturing workforce was sampled to the same extent as was SIC 39, Miscellaneous Manufacturing, which employs about 32 percent of the total manufacturing workforce. This undersampling was considered unaviodable considering time and resource constraints.

The following table displays the geographic distribution of the firms contacted during the survey. As the table 111 ustrates, firms located in twenty-eight (28) communities, employing over 14,800 workers, were surveyed. The totals closely parallel the general distribution of manufacturing firms in Rhode Island, with Providence accounting for the 
the greatest number of firms surveyed, followed by

Pawtucket, Warwick and East Providence.

TABLE B -4

Geographical Distribution of Surveyed Firms

City or Town Number of Firms

Barrington 1

Burrillville 1

Central Falls 5

Coventry 1

Cranston 7

Cumberland 2

East Greenwich 4

East Providence 8

Exeter 1

Hopkinton 1

Johnston 2

Lincoln 2

Middletown 1

Newport 1

North Kingstown 1

North Providence 1

North Smithfield 2

Pawtucket $\quad 14$

Portsmouth 1

Providence 24

Scituate 2

Smithfield 4

South Kingstown 2

Warren 4

West Warwick 3

Westerly 1

Woonsocket 3

Total 107

Approximately 4 percent of the firms engaged in manufacturing enterprises were surveyed, although nearly 10 percent of the total workers employed in manufacturing were surveyed. This proportional difference is the result of 
the samling pla desion to incluce firris aploying nore tian 130 worters as one-tirird of the entire sarnle. As a rejult, jo:se of the larest private manufacturing erployers ir Rinde Island, incluibs cinit moloyers of over ton people and two employers of over 1, non rorliors, were incluced in tie sample.

Research into the use of nail survey techniquas inicated that ticre were a muber of approaches that increase, alveit sligitly, the overall response rate. For exanile, the use of an introductory postcard announcins, that a survey would be forthcoming, the use of First-class mail, a covor letter, a folloiml letter accompanich $\because$ anotiuer copy of the survi?

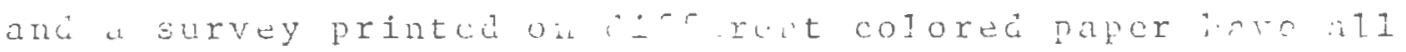
lecin found to increase the response rate in mail surveys. Generally, the response rate in mail surveys is between 42 and 50 percent, with a response rate of 75 percent achicved only rarely and under optimal conditions.

Two other significant variables to the success of the mail survey appoach included the "intrinsic value" factor and the "closed response" approach. The "intrinsic value" factor indicated that the greater the intrinsic interest of the subject of the survey to the questions included in the survey, the higlier the response rate. The "closed resporse" approach indicated that higher response rates vould result if those surveycu could express their viers by selecting among predetermined responses rather than by asling respondents to provice lengthy and time consumingr responses. The closed 
reslonse also facilitates coding and comparability of

responses.

A11 tirese techniques vere utilizer in guiling t'ie develonment and implementation of the survey. Tre survey was designed utilizing the closed response approach, alloring

for 1. in ited explanatory responses. Surveys werc preceeder hy a postcari and the survey includcd a cover letter nnder the signature of the Chief of the phode Island Statowice Planning Program, under whose auspices the survey vas conductec. The survey was printer. on blue pancr and was mailed with a self-addresser, stamped cnvelope learing the Statewide Planning progran aduress. A follorup letter, includiar anoticr copy of tic surve? ard anotier sejf-adressed, stampcd envelope was sent to respondents vho failec to return the initial questionnaire.

In addition, all surveys were addressod to tlif personnel director on the assumption that this person lad, ly virtue of position, the liest vantage point to anster the cuestjons contained in the survey. The personte? diractor, rhother the orrer of the company, as in the case of a imall lusinos or ar indjuidual, as in the case of a larmer comnnn, Tnill iave the rrcatcst interest in tho garsonnel affairs of t'ut cotpany and presurqliy rovid viet the rufstiors continger jn tho survey rjthin tro "intrirsic value" romtort. 


\section{SELECTED BIBLIOGRAPHY}

Congressional Quarterly Almanac, Inc. "Summary of Legislation." Washington, D.C., 1977.

Copperman, Lois F.; Montgomery, Douglas G.; Keast, Fred D. The Impact of the ADEA Amendments of 1978 on the Private Business Community. Portland: Portland State University, 1979.

Halpern, Janice. "Ra1sing the Mandatory Retirement Age: Its Effect on the Employment of Older Workers." New England Economic Review, May-June 1979, pp. 23-35.

Harris, Louls and Associates, Inc. The Myth of Aging in America. Washington, D.C.: National Council on the Ag1ng, 1975 .

Levitan, Sar A.; Mangum, Garth L.; and Marshall, Ray. Human Resources and Labor Markets. New York: Harper and Row, 1972 .

Rhode Island. Commission for Human Rights, Annual Report 1979 (Typewritten).

Rones, Philip L. "0lder Men-the Cholce Between Work and Retirement." Monthly Labor Review, November 1978, pp. 3-10.

Schlel, Barbara L. Employment Discrimination Law. Washington: The Bureau of National Affalrs, 1979 .

Seeberg, Steven. "Cholces Avallable in Amending Plans to Meet the New Age-70 Retirement Rules." Journal of Taxation August 1978, pp. 66-72.

Sullivan, Donald E. "Never Too 01d." The Personnel Administrator. June 1978, pp. 54-58.

The Bureau of National Affairs, "ASPA-BNA Survey No. 39 Retirement Policies and Programs." Washington, D.C., 1980 .

U.S. Congress. House. Active Americans Over 65 Speak on Retirement Age Policies, Committee $\overline{\text { Publication }}$ 95-92, 95th Congress, 1st Session, 1977. 
U.S. Congress. House. Mandatory Retirement: The Soclal and Human Cost of Enforced Idleness, Committee Publ1cation 95-91, 95th Congress, 1st Session, 1977.

U.S. Congress. House. Public Policy and the Future of Work and Retirement, Committee Publication 95-143, 95th Congress, 2nd Session, 1978.

U.S. Congress. Senate. Age Discrimination In Employment Amendments of 1977, Subcommittee on Labor, 95 th Congress, 1st Session, 1977.

U.S. Congress. Senate. The Next Steps in Combating Age Discrimination in Employment: With Special Reference to Mandatory Retirement Policy, A Working Paper, by Marc Rosenblum, Consultant. Special Committee on Aging. Washington, D.C., 1977.

U.S. Department of Labor. Age Discrimination in Employment Act of 1967, A Report Covering Activities Under the Act During 1977 . Washington, D.C.: Government Printing Offick, $197 \overline{7}$.

U.S. Department of Labor. Age Discrimination in Employment Act of 1967, A Report Covering Activities Under the Adt During 1978. Washington, D.C.: Government Printing office, 1978 .

U.S. Department of Labor. Employment and Training Report of the President, 1978. Washington, D.C.: Government Printing office, 1978 .

U.S. Department of Labor. Employment and Training Report of the President, 1979. Washington, D.C.: Government Printing Office, 1979 .

Weaver, Charles $N$. "Workers' Expectation About Losing and Replacing Their Jobs." Monthly Labor Review (April 1980); PP. 53-54.

Work in America Institute. The Future of 01der Workers in America. New York: Scarsdale, 1980 . 